\title{
Site formation and chronology of the new Paleolithic site Sima de Las Palomas de Teba, southern Spain
}

\author{
Martin Kehl ${ }^{\mathrm{a}, *}$, Christoph Burow $^{\mathrm{a}}$, Pedro Cantalejo ${ }^{\mathrm{b}}$, Salvador Domínguez-Bella ${ }^{\mathrm{c}}$, Juan José Durán ${ }^{\mathrm{d}}$, \\ Felix Henselowsky ${ }^{a}$, Nicole Klasen ${ }^{a}$, Jörg Linstädter ${ }^{\mathrm{e}}$, Javier Medianero ${ }^{\mathrm{b}}$, Andreas Pastoors ${ }^{\mathrm{f}}$, José Ramos ${ }^{\mathrm{g}}$, \\ Klaus Reicherter $^{\mathrm{h}}$, Christoph Schmidt $^{\mathrm{a}, \mathrm{i}}$, Gerd-Christian Weniger ${ }^{\mathrm{f}}$ \\ a Institute of Geography, University of Cologne, Albertus Magnus Platz, 50923 Köln, Germany \\ ${ }^{\mathrm{b}}$ Investigador Doctor, Grupo PAI-HUM-440, Spain \\ c Área de Cristalografía y Mineralogía, Departamento de Ciencias de la Tierra, Facultad de Ciencias, Campus Río San Pedro, Puerto Real, Cádiz, Spain \\ d Instituto Geológico y Minero de España (IGME), C/ Ríos Rosas, 23, 28003 Madrid, Spain \\ e Institute of Prehistoric Archaeology, University of Cologne, Albertus Magnus Platz, 50923 Köln, Germany \\ f Stiftung Neanderthal Museum, Talstrasse 300, 40822 Mettmann, Germany \\ g Área de Prehistoria, Departamento de Historia, Geografía y Filosofía, Facultad de Filosofía y Letras, Universidad de Cádiz, Avda Gómez Ulla, s/n, 11003 Cádiz, Spain

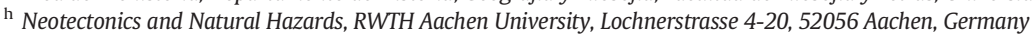 \\ ${ }^{\text {i }}$ Chair of Geomorphology, University of Bayreuth, 95440 Bayreuth, Germany
}

\section{A R T I C L E I N F O}

\section{Article history:}

Received 19 October 2015

Available online $\mathrm{xxxx}$

\section{Keywords:}

Neanderthal occupation

Site formation processes

Micromorphology

Luminescence dating

\begin{abstract}
A B S T R A C T
The newly identified Paleolithic site Sima de Las Palomas de Teba hosts an almost seven-m-thick sediment profile investigated here to elucidate the rock shelter's chronostratigraphy and formation processes. At its base, the sediment sequence contains rich archeological deposits recording intensive occupation by Neanderthals. Luminescence provides a terminus ante quem of $39.4 \pm 2.6 \mathrm{ka}$ or $44.9 \pm 4.1 \mathrm{ka}$ (OSL) and $51.4 \pm 8.4 \mathrm{ka}$ (TL). This occupation ended with a rockfall event followed by accumulation of archeologically sterile sediments. These were covered by sediments containing few Middle Paleolithic artifacts, which either indicate ephemeral occupation by Neanderthals or reworking as suggested by micromorphological features. Above this unit, scattered lithic artifacts of undiagnostic character may represent undefined Paleolithic occupations. Sediment burial ages between about $23.0 \pm 1.5 \mathrm{ka}$ (OSL) and $40.5 \pm 3.4 \mathrm{ka}$ (pIRIR) provide an Upper Paleolithic chronology for sediments deposited above the rockfall. Finally, a dung-bearing Holocene layer in the uppermost part of the sequence contains a fragment of a human mandible dated to $4032 \pm 39{ }^{14} \mathrm{C}$ yr BP. Overall, the sequence represents an important new site for studying the end of Neanderthal occupation in southern Spain.
\end{abstract}

(c) 2016 University of Washington. Published by Elsevier Inc. All rights reserved.

\section{Introduction}

Iberia has a rich Middle Paleolithic record of 70 cave and rock shelter sites documenting occupation by Neanderthals. Most of these sites appear to reflect discontinuity of human occupation after Neanderthals, because the archeological sequences contain Mousterian levels only or do not include Protoaurignacian or Aurignacian assemblages, which are attributed to early anatomically modern humans (AMHs) in Iberia. Less than one-third (28) of the sites contain layers of both Neanderthals

\section{* Corresponding author.}

E-mail addresses: kehlm@uni-koeln.de (M. Kehl), christoph.burow@uni-koeln.de (C. Burow), pedrocantalejo@gmail.com (P. Cantalejo), salvador.dominguez@uca.es (S. Domínguez-Bella),jj.duran@igme.es (J.J. Durán), felix.henselowsky@uni-koeln.de (F. Henselowsky), nicole.klasen@uni-koeln.de (N. Klasen), joerg.linstaedter@uni-koeln.de (J. Linstädter), javiermedianero@gmail.com (J. Medianero), pastoors@neanderthal.de (A. Pastoors), jose.ramos@uca.es (J. Ramos), k.reicherter@nug.rwth-aachen.de (K. Reicherter), christoph.schmidt@uni-bayreuth.de (C. Schmidt), weniger@neanderthal.de (G.-C. Weniger). and early AMHs. Considering that in 14 of these sites the corresponding levels are separated by archeologically sterile layers or sedimentary discontinuities (Mallol et al., 2012), it appears likely that records of discontinuity in human occupation are much more numerous than those documenting continuity.

In southern Spain, several cave and rock shelter sequences document occupation by Neanderthals (Fig. 1). The caves of Carigüela (Fernández et al., 2007), Horá (Vega Toscano, 1988), Higueral de Sierra Valleja (Jennings et al., 2009) and Higueral de Motillas (Giles Pacheco et al., 1998), as well as the rock shelter Complejo del Humo (Ramos et al., 2005; Jennings, 2006; Fig. 1A) were abandoned after Neanderthal occupation and not used by early AMHs. In contrast, Gorham's cave (Pettitt and Bailey, 2000; Finlayson et al., 2006), El Bajondillo (Cortés Sánchez et al., 2008) and the Boqueta de Zafarraya (Barroso and DeLumley, 2006), were occupied by AMHs during the Early Upper Paleolithic as well (Schmidt et al., 2012 and references cited therein). However, the cultural attribution of presumably early Upper Paleolithic levels is still under discussion (Peña, de la and Vega Toscano, 2013; 


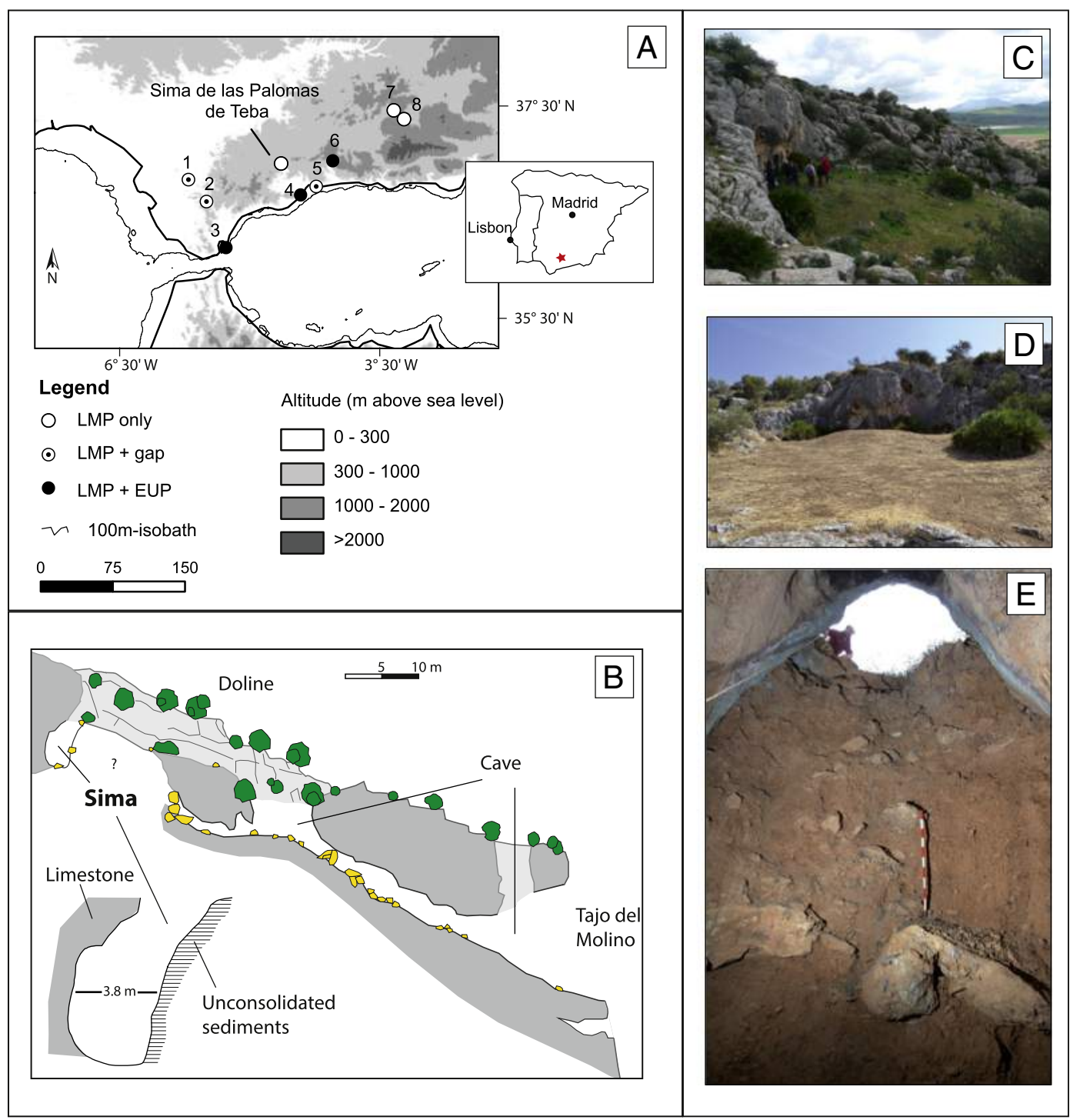

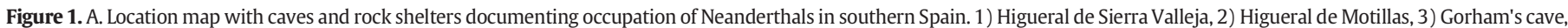

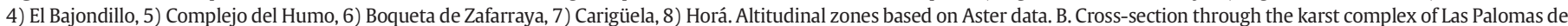

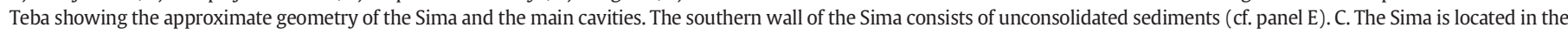

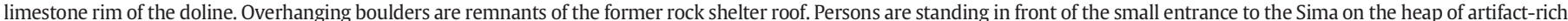

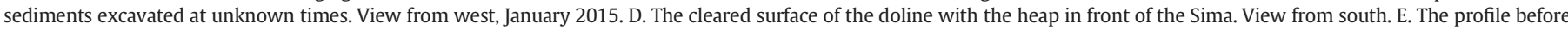

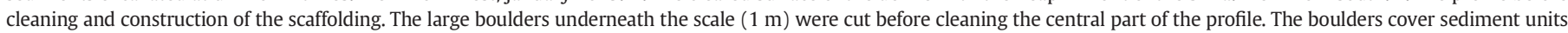
9 and 10 (Fig. 2)

Marreiros and Bicho, 2013) and it appears very likely that dispersion of AMH into the south of the Iberian Peninsula was retarded.

Dating the Late Neanderthals in southern Iberia is a matter of recent dispute. Radiocarbon dating at Gorham's cave (Finlayson et al., 2006), Boquete de Zafarraya (Hublin et al., 1995) or Carigüela (Fernández et al., 2007) apparently suggests a late survival in the South until about $28{ }^{14} \mathrm{C}$ ka BP, equivalent to about 32 cal ka BP. More recent dating efforts demonstrate that these and other previous radiocarbon dates probably underestimated the time of Late Neanderthals in Iberia, which according to new estimates disappeared at the latest around 38 cal ka BP, but probably earlier (Maroto et al., 2012; Kehl et al., 2013a; Michel et al., 2013; Wood et al., 2013; Higham et al., 2014). Causes of age underestimation may relate to poor preservation of bone or contamination with modern ${ }^{14} \mathrm{C}$ in charcoal. Wood et al. (2013) found that $\mathrm{C} / \mathrm{N}$ ratios indicated appropriate collagen preservation in just two out of ten Middle and early Upper Paleolithic sites of southern and central Iberia, stressing the poor suitability of bone for radiocarbon dating in that area. Systematic underestimation of radiocarbon dating on bone in Iberia was also observed by Jöris et al. (2003). Further problems arise from inappropriate definition of archeological context or poor diagnostic value of lithic assemblages of dated layers (e.g., Zilhão, 2006).

Given the uncertainties in radiocarbon dating, independent age control using other radiometric or dosimetric methods is needed. Recently, thermoluminescence (TL) and optically stimulated luminescence (OSL) have been used to date the sediment context of Late Neanderthal occupations at El Salt. Levels VIII to V middle, including the uppermost Mousterian assemblages, were dated to 43 to $54 \mathrm{ka}$, if error margins are included (Galván et al., 2014). U-series dating on three bone samples from the uppermost Mousterian layer at Gruta de Oliveira, Level 8, yielded between 34 and $40 \mathrm{ka}$ (Hoffmann et al., 2013). These dates apparently corroborate radiocarbon dates on two pieces of burnt bone from the same level yielding about $38 \mathrm{cal} \mathrm{ka} \mathrm{BP} \mathrm{(Angelucci} \mathrm{and} \mathrm{Zilhão,}$ 2009). Although there is doubt that dating burned bone produces 
reliable results and considering the critique on previous dating attempts for apparent Late Neanderthal occupations at Gorham's cave, Zafarraya and Carigüela (Zilhão, 2006; Wood et al., 2013), it appears that Level 8 of Gruta de Oliveira currently represents the latest Neanderthals in the south of the Iberian Peninsula.

Dating the arrival of AMH in the south is also problematic. As mentioned above, the cultural attribution of the earliest Upper Paleolithic layers to the Aurignacian is under debate. Radiocarbon dates have been published for a couple of sites. Dates from the sequence at Cova Beneito appear unreliable due to age inversions and problems in stratigraphy (Zilhão, 2006). At Pego do Diabo (Zilhão et al., 2010) and Gorhams's cave (Pettitt and Bailey, 2000), the lowermost AMH levels date to less than $35 \mathrm{cal} \mathrm{ka}$ BP. The earliest Upper Paleolithic of El Bajondillo (Cortéz-Sánchez et al., 2008), was dated to less than $42 \mathrm{cal}$ ka BP, but the two radiocarbon dates for Level 11 are afflicted by large measurement errors and show inconsistencies with results from TL dating. In addition, the sedimentary interface between the Middle and Upper Paleolithic levels shows discontinuities in sediment accumulation (Mallol et al., 2012), suggesting a gap in the stratigraphic record (or even in human occupation).

Additional information on Neanderthal presence in southern Iberia may provide new evidence for the timing and process of Neanderthal extinction. The recently identified archeological site of Sima de Las Palomas de Teba is a partially collapsed rock shelter within Cretaceous limestone. The sediment profile exposed has not been investigated in detail before, but it offers the perspective to study Mousterian occupation in the Guadalteba district. Information recovered from profile analysis so far indicates a series of Middle Paleolithic occupations interrupted by at least one occupation hiatus (Kehl et al., 2013b; Weniger and Ramos Muñoz, 2014). Human presence at the site is fading out in the upper part of the sequence.

Our objectives were to define stratigraphic units and shed light on site-formation processes. In addition, we aimed at providing a chronological framework for sediment accumulation and human occupation in the rock shelter, thereby assessing the potential of the sediment sequence for excavation. The analytical approach encompassed sedimentological and geochemical analyses as well as micromorphological investigations. Micromorphology is a powerful tool to clarify the composition of anthropogenic and natural deposits and the processes of sediment deposition and post-depositional alteration in caves and rock shelters (e.g., Courty et al., 1989; Courty and Vallverdu, 2001; Goldberg and Macphail, 2006; Mallol et al., 2010; Karkanas and Goldberg, 2013; Karkanas et al., 2015). Recently, a couple of studies have demonstrated the suitability of luminescence methods for dating Western European rock shelter sequences (e.g., Guérin et al., 2012, 2015; Kehl et al., 2013a; Galván et al., 2014; Richter et al., 2014; Brown et al., 2015). Here, we apply different luminescence protocols to determine sediment deposition ages and the time of last heating of flint in order to further explore the application of luminescence techniques for providing independent chronologies in these kinds of deposits.

\section{The site}

The Sima is located at $36^{\circ} 59^{\prime} \mathrm{N}$ and $4^{\circ} 53^{\prime} \mathrm{W}$ at $445 \mathrm{~m}$ asl in the Province of Málaga. It is situated about $100 \mathrm{~m}$ below the crest of a southfacing slope within Cretaceous limestone of the Sierra de TebaPeñarrubia. The site overlooks the valley and small alluvial plain of the Guadalteba River, which about $8 \mathrm{~km}$ to the southeast of the site has its confluence with the Turón and Guadalhorce Rivers. Flowing from the southeast, the Guadalteba drains a mountainous area where the highest peaks reach about $1100 \mathrm{~m}$. North of the Sierra de Teba-Peñarubbia, the landscape is slightly undulating. The straight-line distance from the site towards the Gulf of Malaga is about $50 \mathrm{~km}$.

The Sima is part of the northeastern limestone rim of a small doline, which has a diameter of about $20 \mathrm{~m}$ and a smooth surface, sloping towards the southwest (Fig. 1B-D). The limestone rim itself is about $6 \mathrm{~m}$ high. The doline forms a nexus to the karst complex of the Cueva de Las Palomas, which extends downslope towards the gorge of Tajo del Molino (Fig. 1B, Medianero et al., 2011). The actual shape of the Sima resembles a vertical limestone chasm and is at least $9 \mathrm{~m}$ deep. The western, northern and eastern walls are shaped in limestone whereas the southern wall is composed of about $7 \mathrm{~m}$ thick unconsolidated sediments (Fig. 1E) mainly consisting of silty clay loam with varying admixtures of rocks and boulders as well as lithic artifacts, bones, charcoal and mollusk shells. The limestone rim represents the remnant of the former roof of the rock shelter. It is likely that in former times, the cavity was completely filled with sediments before unknown excavators dug out sediment in the rearmost part of the rock shelter and heaped it on the land surface in front of rock shelter (Fig. 1C). The timing of this activity and its purpose are unknown, but it left many lithic artifacts scattered on the surface of the heap indicating the presence of a Middle Paleolithic occupation. It is not known if the Sima was connected to the main cavities of the Las Palomas caves. A series of vibra-corings into the sedimentary fill of the doline did not reach depths larger than $2 \mathrm{~m}$ below land surface.

Modern climate of the area is semiarid Mediterranean (Csa according to KOEPPEN). Mean annual air temperature ranges from 15.0 to $17.5^{\circ} \mathrm{C}$ and mean annual precipitation is between 400 and $700 \mathrm{~mm}$ (Atlas Climático Ibérico, sine anno). Limited data are available on the climate conditions during the past, but marine cores from the Alboran Sea and terrestrial archives in southern Spain clearly reflect changes between dry and cool, and moist and humid conditions during the time of Late Middle Paleolithic occupation. For example, pollen spectra from the Middle Paleolithic layers 19 to 14 at Bajondillo document changes between steppic and forested landscapes (López-Sáez et al., 2007). Lithological, palynological and geochemical records of the Fuentillejo Maar (Vegas et al., 2010; Ortiz et al., 2013) also suggest major climate driven changes in the lake catchment during the last glacial period involving pulses of dry and cold climatic conditions.

A preliminary study of the pollen record of the Sima de Las Palomas de Teba (Ruiz Zapata and Gil, 2014) suggests a decline of forest cover and an increase of open grasslands from bottom to top of the studied profile. Faunal remains retrieved from profile cleaning include bones from Felis silvestris, Equus ferus, Sus scrofa, Bos primigenius, Capra pyrenaica, Cervus elaphus and Oryctolagus cuniculus as well as Ave indet and Chelenonia indet (Espigares et al., 2014). This species assemblage resembles the typical late Pleistocene fauna of Iberia.

\section{Materials and methods}

\section{Field description}

The archeological intervention at the site was limited. Its main purpose was to evaluate the archeological potential of the site. Before field inspection and sampling, a profile was prepared in the unconsolidated sediments of the south wall of the Sima. Overhanging boulders were cut and the central part of the exposure was cleaned and documented (Fig. 2 left). The locations of flint, bone, charcoal and mollusk shells were recorded for the entire width of the exposure (Fig. 2 right).

In the field, we divided the sequence into major units based on stone content, sediment color and general structure. Results of sedimentological and geochemical laboratory investigations were used for further subdivision resulting in ten different sediment units. The uppermost unit 1 (Fig. 2) is an artificial modern deposit of unknown age. Unit 2 mainly consists of large boulders exposed on the eastern side of the profile. These boulders probably mark the last collapse of the shelter roof. Unit 3 is a grayish layer with common stones and boulders, silty matrix and a low degree of compaction due to bioturbation. Within this layer, sediment color slightly changes from dark gray at the top of the unit to light reddish brown in the lower half related to differential accumulation of organic matter (humus). The lower boundary of unit 3 is 


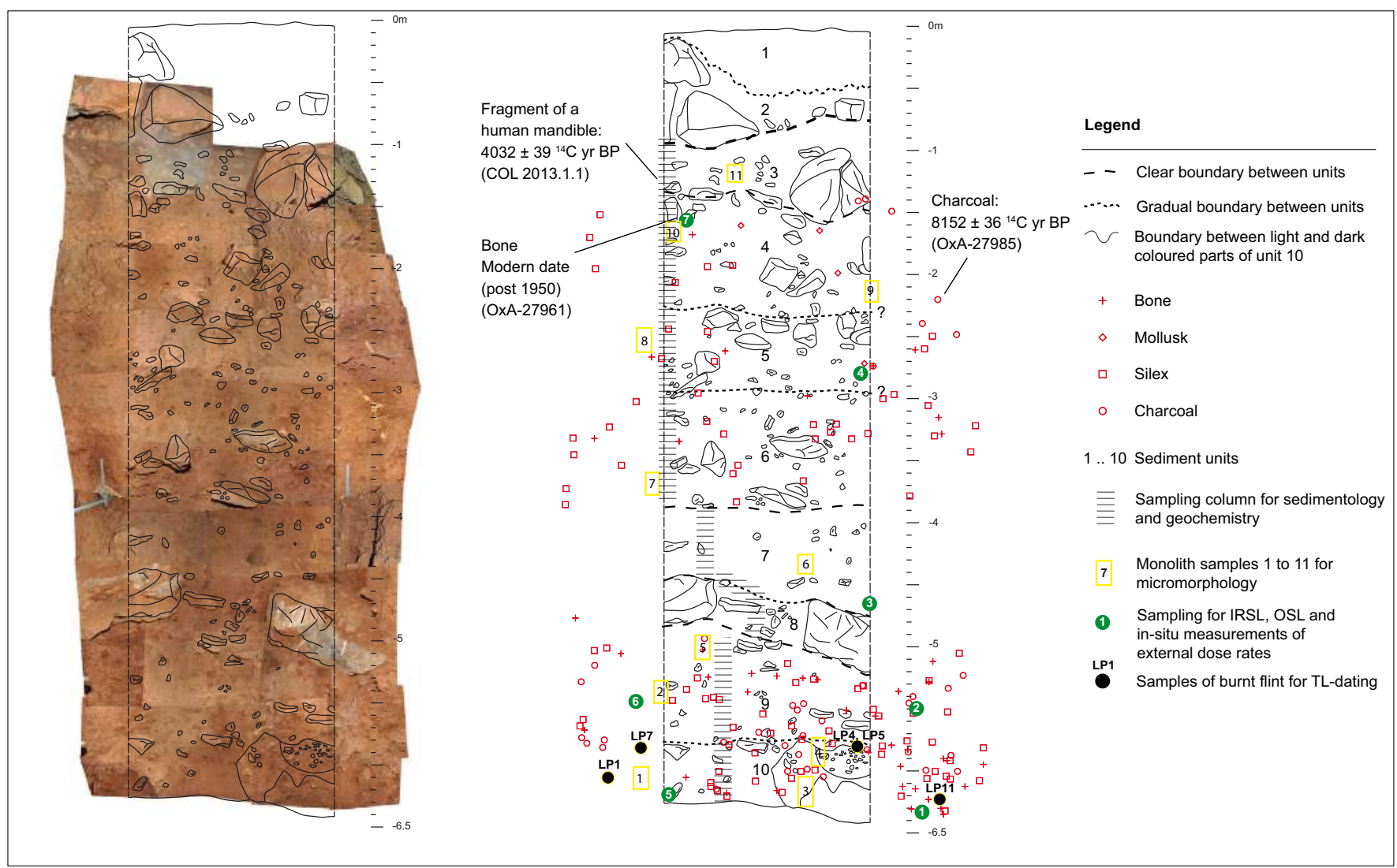

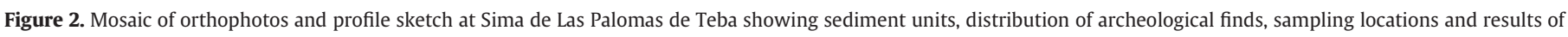

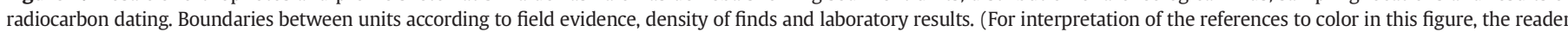
is referred to the web version of this article.)

sharp. Units 4 to 6 consist of light reddish brown silty to clayey matrix with variable amounts of angular to subrounded stones and boulders. The stones are in chaotic arrangement and appear to float in the matrix. Locally, the stones are concentrated in discontinuous sediment packages. Although clear interfaces between these units are lacking, the data on sediment color, magnetic susceptibility and geochemistry (see below) suggest a distinction into separate layers with gradual transitions. Units 4 to 6 contain dispersed lithic artifacts (Fig. 2), pieces of bone and charcoal and mollusk fragments. In contrast, the underlying units 7 and 8 appear to be archeologically sterile, because no relevant material was found during cleaning and sampling of the profile. From a lithological perspective, a clear boundary between units 6 and 7 is difficult to identify in the field, but unit 7 has a slightly lighter color and lacks archeological material. Unit 8 is composed of large boulders, which represent a roof fall episode. In between the boulders, stonerich silty clay loams accumulated. The properties of the fine fraction resemble those of unit 7 . Below unit 8 reddish brown silty clay loams of unit 9 and dark gray loams of unit 10 are exposed. Here, the matrixsupported fabric expressed in units 3 to 7 locally grades into a clastsupported one. Both units contain large amounts of lithic artifacts as well as charcoal and bone fragments. In unit 10, several layered accumulations of dark gray sediment rich in bone and charcoal are present, which resemble hearth features.

\section{Sedimentology and geochemistry}

Sediment samples were extracted along a vertical column at intervals of five or ten cm (Fig. 2). After air-drying and dry-sieving, all subsequent analyses were conducted on the fine size fraction ( $<2 \mathrm{~mm}$ in diameter), if not otherwise indicated. Determination of the granulometric composition of the siliceous fine fraction (destruction of carbonate with $10 \%$ $\mathrm{HCl}$, dispersion with $0.01 \mathrm{M} \mathrm{Na}_{4} \mathrm{P}_{2} \mathrm{O}_{7} \cdot 10 \mathrm{H}_{2} \mathrm{O}$ ) was measured using a laser diffractometer (Beckman Laser Coulter LS13320). Volumetric magnetic susceptibility ( $\kappa$ ) was determined using a Bartington MS2 spectrometer equipped with the MS2K sensor. Soil color was measured for homogenized samples of the fine fraction in triplicates with a spectrophotometer (Konica Minolta CM-5) by detecting the diffuse reflected visible light in the 360 to $740 \mathrm{~nm}$ range under standardized observation conditions ( $2^{\circ}$ Standard Observer, Illuminant $C$ ). The spectral information was converted into Munsell values and into the CIELAB Color Space system using the Software SpectraMagic NX (Konica Minolta). The carbonate content of the fine fraction was determined volumetrically by measuring the production of $\mathrm{CO}_{2}$ after addition of $4 \mathrm{M} \mathrm{HCl}$ and expressed as calcium carbonate equivalent (CCE). The composition of major and trace elements was measured with a Spectro Xepos HE X-ray fluorescence (XRF) spectrometer on pressed pills prepared using the silt and clay fraction $(<63 \mu \mathrm{m})$.

\section{Micromorphology}

A series of 15 thin sections ( $60 \mathrm{~mm} \times 80 \mathrm{~mm}$ in length, 30 - $\mu \mathrm{m}$ thick) was prepared from 11 sediment monoliths extracted from different sediment units (Fig. 2) and wrapped in plaster bandages. Thin section preparation was carried out by Th. Beckmann, Schwülper-Lagesbüttel, Lower Saxony, Germany. Descriptions of thin sections followed Stoops (2003). The properties of groundmass and pedofeatures were observed at different scales of observation using a flatbed scanner and the petrographic microscope under plane polarized light (PPL) or crossed polarizers (XPL). 


\section{Radiometric and dosimetric dating}

\section{Radiocarbon dating}

During preparation of the profile and extraction of sediment samples, three samples were collected for AMS radiocarbon dating at the laboratories in Cologne (CologneAMS) and Oxford (ORAU). The uppermost sample collected in sediment unit 3 (Fig. 2) is a tooth originating from a maxillar fragment of a child, probably four years old (sample number COL 2013.1.1). For analytical procedures of sample preparation in the Cologne lab refer to Rethemeyer et al. (2013). The other samples consisted of undetermined bone (OxA-27961) from unit 4 and charcoal (OxA-27985) retrieved from the surface of the profile after cleaning. In addition, five macroscopically well preserved bone fragments were selected from sediment unit 9 in order to provide independent ages for this level. Unfortunately, collagen yield of these samples was insufficient to allow for ${ }^{14} \mathrm{C}$ determination. The poor preservation of bone in south Iberian cave settings is a common observation (Wood et al., 2013). We therefore did not further test other bone fragments.

\section{IRSL/OSL-dating}

For estimating the time of sedimentation optically stimulated luminescence (OSL) was performed on five sediment samples extracted from different depths in sediment units 10, 9, 7, 5 and 4 (Fig. 2). The samples were extracted using opaque metal tubes to prevent early resetting of the luminescence signal. All preparation procedures of the determination of the equivalent dose were carried out under subdued red illumination. The samples were chemically treated with hydrochloric acid ( $\mathrm{HCl} 10 \%)$, hydrogen peroxide $\left(\mathrm{H}_{2} \mathrm{O}_{2} 10 \%\right)$ and sodium oxalate $\left(\mathrm{Na}_{2} \mathrm{C}_{2} \mathrm{O}_{4}\right)$ to dissolve any carbonates, oxidize organic matter and to disperse the fine grain fraction. Coarser grained samples (CP1, CP4) were dry sieved to $100-200 \mu \mathrm{m}$, followed by mineral separation using sodium polytungstate to obtain quartz $\left(2.62-2.68 \mathrm{~g} \mathrm{~cm}^{-3}\right)$ and potassium-rich feldspar $\left(<2.58 \mathrm{~g} \mathrm{~cm}^{-3}\right)$. The enriched quartz fraction was further etched in hydrofluoric acid (HF 40\%) for 40 min to remove any remaining feldspars and the outer alpha-irradiated layer of the quartz grains. For finer grained samples (CP2, CP3 and CP7) the 4-11 $\mu \mathrm{m}$ fraction was extracted instead, applying the same basic chemical treatment as described above. Polymineralic subsamples were kept for infrared stimulated luminescence (IRSL), while the rest was etched in hexaflourosilicic acid $\left(\mathrm{H}_{2} \mathrm{SiF}_{6} 34 \%\right)$ for 14 days to obtain purified quartz extracts. Coarse-grained quartz and feldspar were mounted to the central $1 \mathrm{~mm}$ of $9.8 \mathrm{~mm}$ diameter stainless steel discs using silicon spray, while fine grains were deposited on the whole area of the steel discs.

The environmental dose rate was estimated using a high-resolution gamma-ray spectrometer with a high-purity Ge detector. Material for dose rate estimation was collected from the surrounding sediments of the OSL sample holes. The samples were oven dried for at least $24 \mathrm{~h}$, ground and filled in Marinelli beakers of defined geometries. Due to ${ }^{222} \mathrm{Rn}$ emanation and prior to measurement the samples were kept in storage for at least four weeks to re-establish secular equilibrium. To account for external $\alpha$-dose rate an $a$-value of $0.07 \pm 0.02$ for feldspar samples (Preusser et al., 2005) was used. Additionally, for all feldspar samples a K concentration of $12.5 \pm 0.5 \%$ (Huntley and Baril, 1997) and an internal ${ }^{87} \mathrm{Rb}$ content of $400 \pm 100 \mathrm{ppm}$ (Huntley and Hancock, 2001) were assumed. The cosmic dose rates were calculated according to Prescott and Hutton (1994), taking into consideration the altitude $(451 \mathrm{~m})$, latitude $\left(37.7997^{\circ}\right)$ and longitude $\left(0.8958^{\circ}\right)$ of the sampling site, as well as the density $\left(2.0 \mathrm{~g} \mathrm{~cm}^{-3}\right)$ and thickness (1.55-6.25 m) of the overlying sediments. We further considered the absorption of the cosmic rays in the bedrock overarching the profile by adding an additional absorber of $7 \mathrm{~m}$ thickness and density of $2.60 \mathrm{~g} \mathrm{~cm}^{-3}$.

All OSL measurements were made using automated Risø TL/OSL DA20 readers equipped with ${ }^{90} \mathrm{Sr} /{ }^{90} \mathrm{Y}$ beta sources delivering dose rates between $\sim 0.09 \mathrm{~Gy} \mathrm{~s}^{-1}$ and $\sim 0.15 \mathrm{~Gy} \mathrm{~s}^{-1}$. Optical stimulation of quartz samples was performed at $90 \%$ power (max. $40 \mathrm{~mW} \mathrm{~cm}^{-2}$ ) using blue diodes (470 $\pm 30 \mathrm{~nm}$ ) for 40 s. Coarse-grained feldspar and polymineralic fine grain samples were measured at $90 \%$ power (max. $145 \mathrm{~mW} \mathrm{~cm}^{-2}$ ) using infrared diodes $(880 \pm 80 \mathrm{~nm}$ ) for $200 \mathrm{~s}$. OSL signals were detected with an EMI 9235 photomultiplier-tube through a 7.5-mm-thick Hoya U340 filter for quartz and through a 5-mm-thick interference filter for feldspar (D410 LOT Oriel, peak transmission at $410 \mathrm{~nm}$ ). The quartz samples were measured using a standard single aliquot regenerative (SAR) protocol after Murray and Wintle $(2000,2003)$. This included blue LED stimulation for $40 \mathrm{~s}$ at $125^{\circ} \mathrm{C}$, a preheat treatment before optical stimulation to measure the natural and regenerative signals and a cut heat treatment with a temperature of $20^{\circ} \mathrm{C}$ below the preheat temperature for test dose measurements. The IR depletion ratio (Duller, 2003) was measured at the end of the SAR sequence to check for any feldspar contamination. Values for the test dose $\left(T_{X}\right)$ and regenerative dose $\left(L_{X}\right)$ signals were derived from the initial $0.8 \mathrm{~s}$ of the OSL signal, minus a background estimated from the last $5.0 \mathrm{~s}$ of the stimulation curve. To determine the most appropriate preheat temperature a series of preheat-plateau tests was conducted. Additionally, dose-recovery tests (DRT) and combined preheat-plateau dose-recovery tests were carried out to check the suitability of the applied dating protocol. Polymineralic fine grain and coarse-grained feldspar samples were measured using elevated temperature IRSL protocols after Buylaert et al. (2009, pIRIR 225 ) and Thiel et al. (2011, pIRIR 290$). L_{x}$ and $T_{x}$ values were derived from the first $2.4 \mathrm{~s}$ of the postIR-IRSL signals, respectively, while subtracting a background of the last $20 \mathrm{~s}$. Likewise, a series of DRTs was carried out to check the performance of the protocols. The natural signal was removed in a Hönle SOL2 solar simulator for $4 \mathrm{~h}$. Residual doses determined on separate aliquots after $24 \mathrm{~h}$ bleaching were subtracted. The most appropriate prior-IR stimulation temperature was obtained in a laboratory experiment (Buylaert et al., 2012) using a range of different temperatures from $50-220^{\circ} \mathrm{C}$. Additional IRSL measurements (Wallinga et al., 2000; Preusser, 2003) using the $50^{\circ} \mathrm{C}$ feldspar signal $\left(I_{50}\right)$ were done for coarse-grained feldspar of samples CP1 and CP4. Fading tests were carried out to quantify potential anomalous fading of this signal. The determined $g$-values were used to correct for the loss of signal over time using the approach of Huntley and Lamothe (2001) and Auclair et al. (2003).

For all OSL and IRSL measurements the rejection criteria for the recycling ratio limit (10\%), test dose error $(10 \%)$ and recuperation rate ( $5 \%$ of the natural signal) were applied to reject aliquots that have luminescence signals that are not appropriate for the SAR procedure. The errors on the rejection criteria were not considered. For samples exhibiting no overdispersion the common age model (Galbraith et al., $1999)$ was used to calculate the equivalent dose $\left(D_{\mathrm{e}}\right)$ for age calculation. The $D_{\mathrm{e}}$ of all other samples was calculated using the central age model (Galbraith et al., 1999).

\section{TL-dating on heated flint}

Thermoluminescence (TL) dating of heated artifacts provides the most direct ages of a site's human occupation since the heating event is in most cases immediately linked to anthropogenic fires (Richter et al., 2009; Schmidt, 2013). Therefore, an initial temporal assignment of the lithic finds was attempted by TL analysis of nine artifacts showing signs of strong heating (e.g., color change, craquelation). Sample preparation included mechanical discarding of a $2 \mathrm{~mm}$ rim with a watercooled diamond saw to remove material influenced by light and external $\beta$-radiation. Especially for translucent samples, attention was paid to using only material not affected by penetrating light. The inner core of artifacts was gently crushed to grain sizes of $100-200 \mu \mathrm{m}$ in a steel mortar and subsequently treated with $10 \% \mathrm{HCl}$ to remove carbonates. Determination of $\alpha$-efficiency was carried out on fine grained material ( 4-11 $\mu \mathrm{m})$, obtained by settling in acetone using Stokes' law. Here, TL resulting from $\alpha$ - and $\beta$-radiation was compared to calculate the $b$-value (Bowman and Huntley, 1984). 
To test the artifacts for sufficient ancient heat impact and thus for the suitability for TL dating, a heating-plateau test was conducted. A DRT was then carried out with most samples passing this test (i.e., showing a constant ratio of natural TL and TL after additive irradiation for temperatures $>260^{\circ} \mathrm{C}$ ), using a recovery dose in the range of the expected paleodose, as indicated by test measurements. Because not enough material for multiple-aliquot measurement protocols was left after sample preparation (due to small artifact size), a singlealiquot regenerative (SAR; Murray and Wintle, 2000) procedure had to be applied for equivalent dose $\left(D_{\mathrm{e}}\right)$ determination of all samples (see Table 1 for details on the used protocol). The results of the SARDRT were taken as a measure for the accuracy of the protocol, although it is clear that an absolute accuracy check requires independent age control. The SAR sequence consisted of four regenerative cycles with increasing doses, plus a zero dose and a repeat point (lowest regeneration dose). Measurements of a fixed test dose $\left(T_{x}\right)$ in between regeneration cycles (yielding $L_{x}$ ) allowed correcting for sensitivity changes during repeated heating and irradiation by using $L_{x} / T_{x}$ to build the growth curve. A single-saturating exponential fit through the dose points established a functional relationship between sensitivitycorrected TL $\left(L_{x} / T_{x}\right)$ and administered dose. All aliquots yielding a recycling ratio outside the range $0.9-1.1$ were rejected. The errorweighted mean of all accepted aliquots gave the final $D_{\mathrm{e}}$.

Prepared coarse-grain samples were attached to stainless steel discs with silicone oil using an 8-mm spray mask, while fine grains were deposited on aluminum discs. TL measurements were conducted in $\mathrm{N}_{2}$ atmosphere with a Risø TL/OSL DA-20 reader, equipped with an EMI 9235QB photomultiplier tube (PMT) for light detection and a Semrock BrightLine HC475/50 interference filter (transmission maximum at $475 \mathrm{~nm}$, FWHM $50 \mathrm{~nm}$ ) between sample and PMT. Heating rate was set to $5^{\circ} \mathrm{C} \mathrm{s}^{-1}$ and the maximum temperature to $450^{\circ} \mathrm{C}$. The subsequently measured thermal background was subtracted from the first curve to obtain the net sample signal. ${ }^{90} \mathrm{Sr} /{ }^{90} \mathrm{Y} \beta$-source delivered $\sim 0.12 \mathrm{~Gy} \mathrm{~s}^{-1}$ to the coarse grains, and a mono-energetic ${ }^{241} \mathrm{Am}$ source of $\sim 30 \mathrm{MBq}$ strength induced $\sim 0.813 \mu \mathrm{m}^{-2} \mathrm{~min}^{-1}$ of $\alpha$-tracks in a monolayer of fine grains.

In addition to TL measurements, an optically stimulated luminescence (OSL) SAR protocol was used to obtain the $D_{\mathrm{e}}$ for sample LP7. The difference in $\alpha$-efficiency for TL and OSL requires determining the $b$-value separately for each stimulation mode. All details related to OSL measurements of LP7 are given in Schmidt and Kreutzer (2013).

Internal dose rates of artifacts were determined by measuring radioelement concentrations (K, Th, U) by ICP-MS (Geological Institute, University of Cologne) using finely ground representative material of the artifacts' cores. Concentrations were then transformed into effective dose rates applying published conversion factors (Adamiec and Aitken, 1998) and the calculated $b$-value. External dose rates from surrounding sediment were assessed by in-situ measurements with the $\gamma$-probe using the holes from OSL sampling. For individual TL samples, the dose rate values determined at the locations closest to their find spots in the profile were chosen for age calculations. Since sediments in karst caves are characterized by abundant limestone rocks and blocks of varying size, heterogeneities of the external radiation is expected.

Table 1

TLSAR protocol used for De determination of the heated silex artifacts. The SAR protocol includes a background measurement (TL to $450^{\circ} \mathrm{C}$ ) subsequent to each TL measurement.
1. TL to $450^{\circ} \mathrm{C} \rightarrow \operatorname{Ln}$
2. Give test dose $15 \mathrm{~Gy}$
3. $\mathrm{TL}$ to $450^{\circ} \mathrm{C} \rightarrow \mathrm{Tn}$
4. Give regeneration dose
5. $\mathrm{TL}$ to $450^{\circ} \mathrm{C} \rightarrow \mathrm{Lx}$
6. Give test dose $15 \mathrm{~Gy}$
7. $\mathrm{TL}$ to $450^{\circ} \mathrm{C} \rightarrow \mathrm{Tx}$
8. Return to step 4

This was accounted for by increasing the uncertainty of the external dose rate to cover deviations from the measured values, which the samples could have experienced in the worst case. An additional amount of uncertainty was added corresponding to a $~ 10 \%$ moisture fluctuation over burial time. Due to the small size of all dated artifacts, internal $\gamma$-absorption was considered as negligible. The cosmic dose rate was calculated as described for IRSL/OSL dating of sediment samples.

\section{Lithic material}

In the course of systematic profile cleaning, 357 lithic artifacts were documented in their stratigraphic position. The analysis of the lithic assemblage focuses on the reconstruction of the technological production sequence as well as the formal tools. We did a typological sorting of cores and blanks with technological descriptions of the process involved in core configuration (Bar-Yosef and van Peer, 2009). Blanks themselves were analyzed according to their technological validity.

Technological terms and definitions adhere mainly to the work of Boëda, Geneste and Meignen (Boëda, et al., 1991; Boëda, 1994; Révillion and Tuffreau, 1994; Delagnes and Meignen, 2006).

The differentiation between Levallois recurrent centripetal and unifacial discoidal cores is problematic and has been object of several discussions (Peresani, 2003). Our analysis cores, which are configured following the unifacial discoidal method, are subsumed under the Levallois recurrent centripetal method. Formal tools were categorized following Bordes (1961) and Bosinski (1967).

\section{Results}

\section{Sedimentology}

The grain-size distribution of the siliceous fines $(<2 \mathrm{~mm})$ was dominated by silt ( 60 to about $80 \%$ ), whereas sand and clay amounted to about 30 and $10 \%$, respectively. The frequency distributions were polymodal. The median grain size showed coarsening in units 6 and 9 (Fig. 3). There was a tendency of decreasing median grain size with depth. An opposite trend is delineated by magnetic susceptibility $(\kappa)$, which attained minimum but highly variable values in unit 3 , increased towards moderate values in units 6,7 and 8 and finally reached maximum values in units 9 and 10 .

The $\mathrm{L}^{*}$-value represents lightness of the sediment, which was lowest in the dark-colored unit 10 and reached maximum values at the interface between units 3 and 4 . In cave sediments, lightness may relate to content of organic matter $(\mathrm{OM})$ with low $\mathrm{L}^{*}$-values reflecting high $\mathrm{OM}$ content and vice versa. Considerable scatter in lightness within sediment units reflects changes in OM content within a sediment unit, hence, incomplete mixing and homogenization. In the case of unit 3, a possible subdivision in layers not detected in the field should be considered. The redness rating displayed a more consistent picture with high ratings in the intermediate part of the sequence, low values in units 10 and very low ratings in unit 3 . The redness of sediments is related to the formation of hematite during pedogenesis, with low values reflecting lower intensities of soil formation. However, low redness ratings may also result from reduced hematite formation due to the presence of organic matter. In units 10 and 3 formation of hematite due to burning must also be considered. The CCE ranged between 20 and $55 \%$, with minimum values in sediment unit 9 and maximum in unit 3. There is a general tendency of decreasing CCE values with depth.

The geochemical composition of the fine fraction $(<63 \mu \mathrm{m})$ was dominated by $\mathrm{Ca}$ ( 8.5 to $25 \%$ ), $\mathrm{Si}$ (7.5 to $18 \%$ ), $\mathrm{Al}$ (2.8 to $7.2 \%$ ), and $\mathrm{Fe}$ (1.8 to $4.2 \%$ ). Potassium (0.8 to $2.1 \%$ ), $\mathrm{Mg}$ (0.6 to $1.2 \%$ ), $\mathrm{Na}(0.4$ to $0.9 \%), \mathrm{P}(0.3$ to $0.9 \%)$ and $\mathrm{Ti}(0.2$ to $0.5 \%)$ were present in subordinate amounts. While depth plots of $\mathrm{Si}, \mathrm{Al}, \mathrm{K}$ and $\mathrm{Ti}$ showed close similarities (Suppl. Fig. S1) reflecting the input of siliceous minerals, the Ca values and less clearly $\mathrm{Sr}$ were negatively correlated with the former ones (Suppl. Fig. S1). The Ca contents were strongly correlated to CCE 


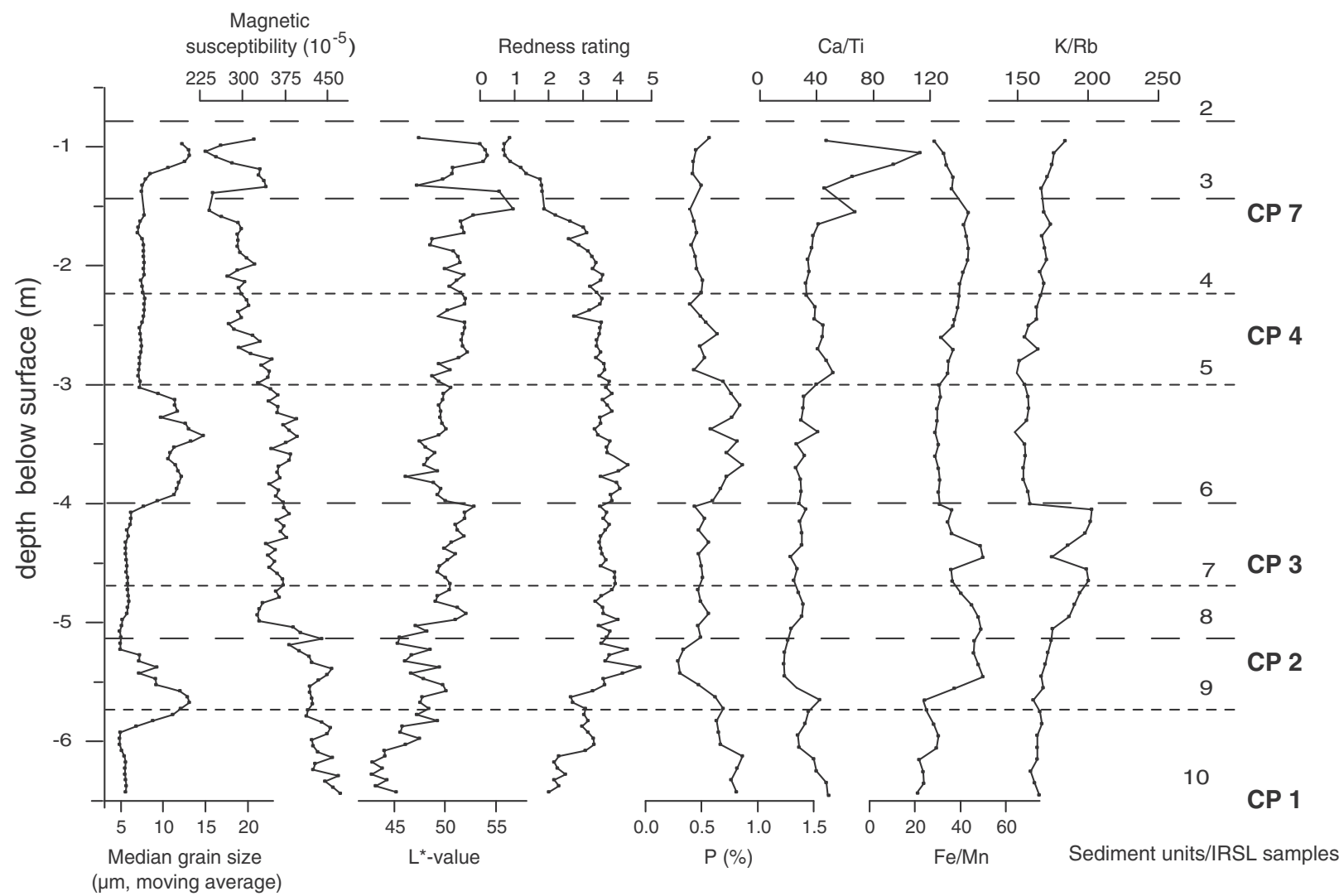

Figure 3. Sedimentological and geochemical properties of the profile at Sima de Las Palomas de Teba. Samples were taken along the sediment column shown in Fig. 2.

(PEARSON $\mathrm{r}=0.964, \alpha=0.05, \mathrm{n}=55$ ), showing that most of the calcium relates to carbonates. The P content was below $1 \%$ and showed high values in units 6 and 10, where comparatively high numbers of archeological finds were present. Slight enrichments with K occurred in units 7 to 9 . Trace element contents showed variance between and within sediment units as well. Zirconium, $\mathrm{Zn}, \mathrm{Cu}, \mathrm{Sr}$ and $\mathrm{Rb}$ suggested that units 4 to 7 have similar trace element signatures, but $\mathrm{Pb}, \mathrm{Ni}$ and Ba showed considerable variation within these units.

Overall, trace elements suggest that units 3 and 9/10 have specific geochemical signatures as anticipated before. The high content of carbonates compared to silicates in unit 3 was reflected by the $\mathrm{Ca} / \mathrm{Ti}$ ratio, which strongly increased in unit 3. A sudden increase in the $\mathrm{K} / \mathrm{Rb}$ ratio at the interface of unit 7 with overlying unit related to increased $\mathrm{K}$ contents.

\section{Micromorphology}

Detailed analyses of the types and abundances of major components detected under the microscope are beyond the scope of this paper. In the following, we give a general description of components found. Subangular fragments of massive, mostly micritic limestone were abundant in all thin sections. Few fragments of stalagmitic crusts occurred as well. Both components originate from spalling off the cave wall. The limestone fragments showed a low degree of corrosion reflecting limited post-depositional weathering. Limestone fragments and calcite grains also occurred in the sand and silt size fractions, in particular in thin section CP M11 from sediment unit 3, where calcite grains, 10 to $20 \mu \mathrm{m}$ in diameter, were abundant. Few polycrystalline quartz and ferricrete sand grains were present. Other mineral components are pieces of flint and chert, which showed characteristic features of knapped lithic artifacts (Angelucci, 2010). Lithic tools from the Sima consist of four different varieties of flint, three radiolarite facies as well as sandstone (Domínguez-Bella et al., 2014). In thin sections from unit
10 in the lower part of the sequence (Fig. 4) stone artifacts were abundant, whereas few pieces were detected in thin sections from sediment units 9 and 5. No knapped lithic artifacts were found in thin sections from sediment units 3, 4, 6 and 7 (Fig. 5).

Phosphate occurred in bone fragments and as anorthic phosphate nodules. The nodules probably represent droppings of small carnivores and less often of birds. Phosphate very rarely occurred as light gray incomplete infillings in sediment unit 10 , which we take as an indication for limited dissolution and re-precipitation of phosphate in the cave deposits of the Sima.

The most frequent constituents of organic origin were angular bone fragments (Figs. 4, 6A) in variable states of burning and preservation. Also, small charcoal pieces occurred throughout the sequence. In thin sections from unit 10 , microsparitic ( 5 to $20 \mu \mathrm{m}$ in diameter) calcite crystals were present in pores and intermixed in the groundmass. These calcite crystals resemble calcite pseudomorphs after calcium oxalate, which originate from burning of woody plant material (e.g., Canti, 2003; Durand et al., 2010). However, distinct microlayers of ash or patchy ash accumulations were not apparent, and there was no close spatial relation of the microsparite to burned bone or charcoal. This lack of evidence for the presence of ash may be explained by post-depositional mixing due to bioturbation and recrystallization of ash particles. In thin section $\mathrm{CP}$ M11 calcite spherulites (10 to $20 \mu \mathrm{m}$ in diameter) occurred as clusters associated with comparatively large numbers of phytoliths. Locally, ellipsoid structure resembling dung pellets were present.

The larger particles of the groundmass were embedded in light gray (CP M11, Fig. 6E) or reddish brown to dark brown (other thin sections) clayey silts (Figs. 4, 5). The fine soil material had a dotted appearance mostly due to humic stains. Interference colors were yellow orange or, in the case of calcitic groundmass, very bright. The b-fabric was mostly crystallitic, but calcite-depleted reddish brown or dark brown soil peds also showed stipple-speckled b-fabric. The coarse/fine-related distribution was open porphyric throughout. 

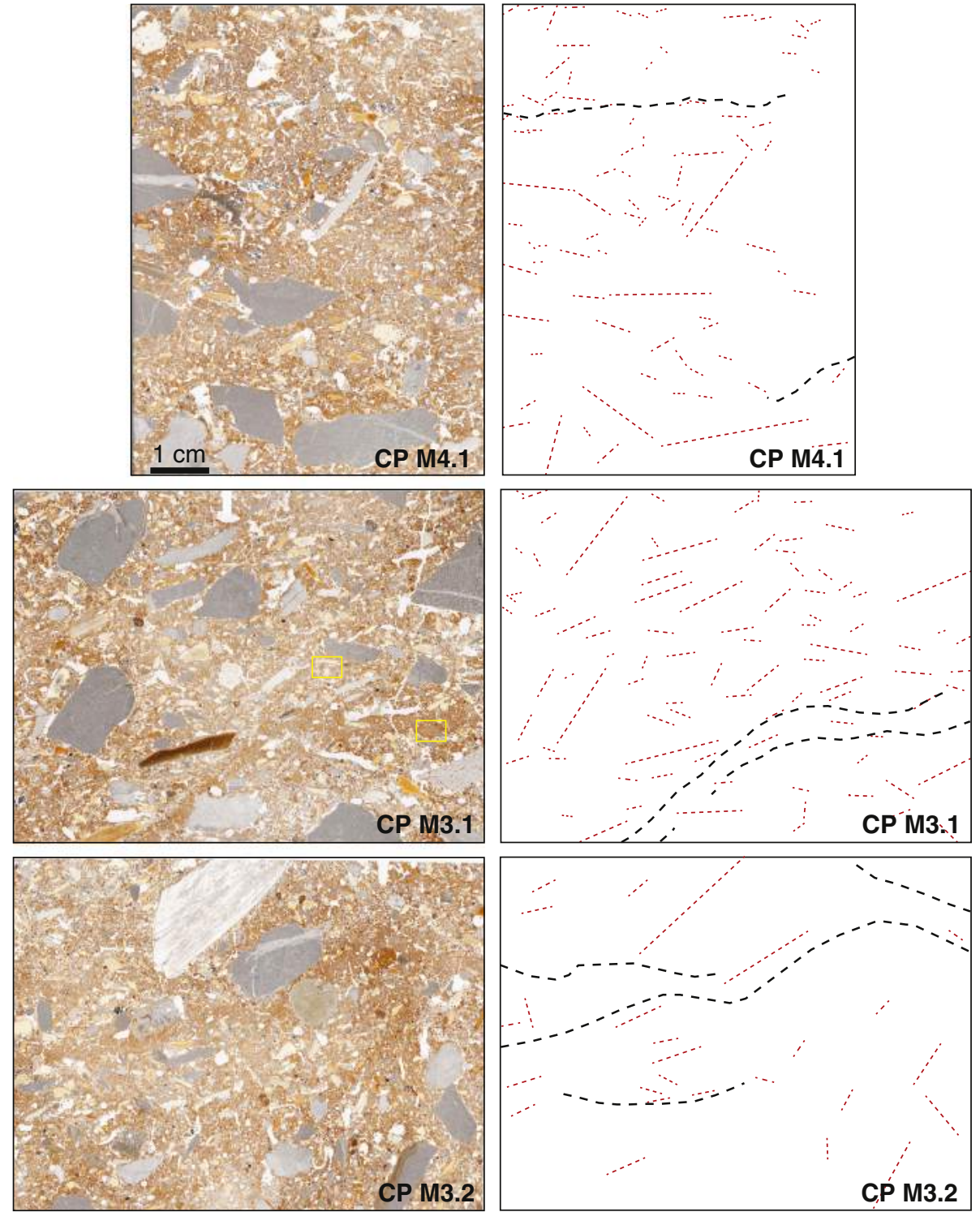

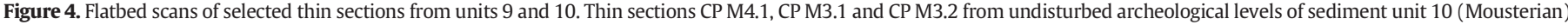

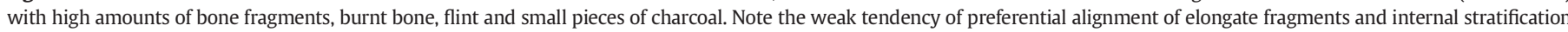

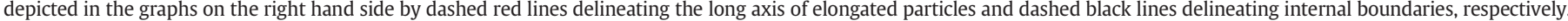

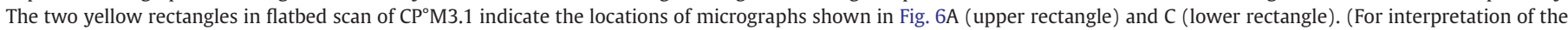
references to color in this figure legend, the reader is referred to the web version of this article.)

The micromorphological properties of the sediment units are described in Table 2. Overall, thin sections from unit 10 showed specific features not found in other units such as very high contents of bone and burnt bone, a tendency to preferential orientation of elongate fragments, presence of microstratification (Courty, 2001) and remnants of surface seal (Pagliai and Stoops, 2010) as well as a differential degrees of compaction within the thin sections (Fig. 4). Thin sections from unit 9 displayed similar sediment properties; the abundance of bone and charcoal, however, was considerably less than in unit 10. In contrast to units 9 and 10, thin sections from units 4 to 7 showed random fabric of elongate fragments, complete lack of microstratification and much lower abundance of bone and charcoal (Fig. 5). Burnt bone was not observed. Finally, the thin section CP M3 from unit 3 had peculiar micromorphological characteristics including a calcitic groundmass, presence of calcite spherulites (Fig. 6E, F) constituting large parts of the groundmass and dung pellets as well as comparatively high abundance of phytoliths, which testify to unique site formation processes during accumulation of this unit. The different nature of sediments from unit 3 is also reflected by sedimentological and geochemical properties.

\section{Radiocarbon dating}

The tooth from the fragment of a human mandible from sediment unit 3 yielded a radiocarbon age of $4032 \pm 39{ }^{14} \mathrm{C}$ yr BP (COL2013.1.1, Fig. 2), which after calibration was equivalent to $4500 \pm 60 \mathrm{cal}$ yr BP. Sample OxA 27961 on bone taken from about $30 \mathrm{~cm}$ below in unit 4 gave a modern age $(\mathrm{F} 14 \mathrm{C}=1.06078 \pm 0.00286)$. Finally, the charcoal

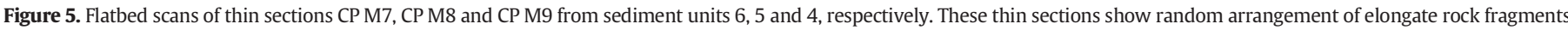

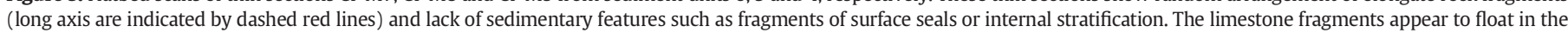
matrix. Note very limited amount of bone and charcoal. (For interpretation of the references to color in this figure legend, the reader is referred to the web version of this article.) 

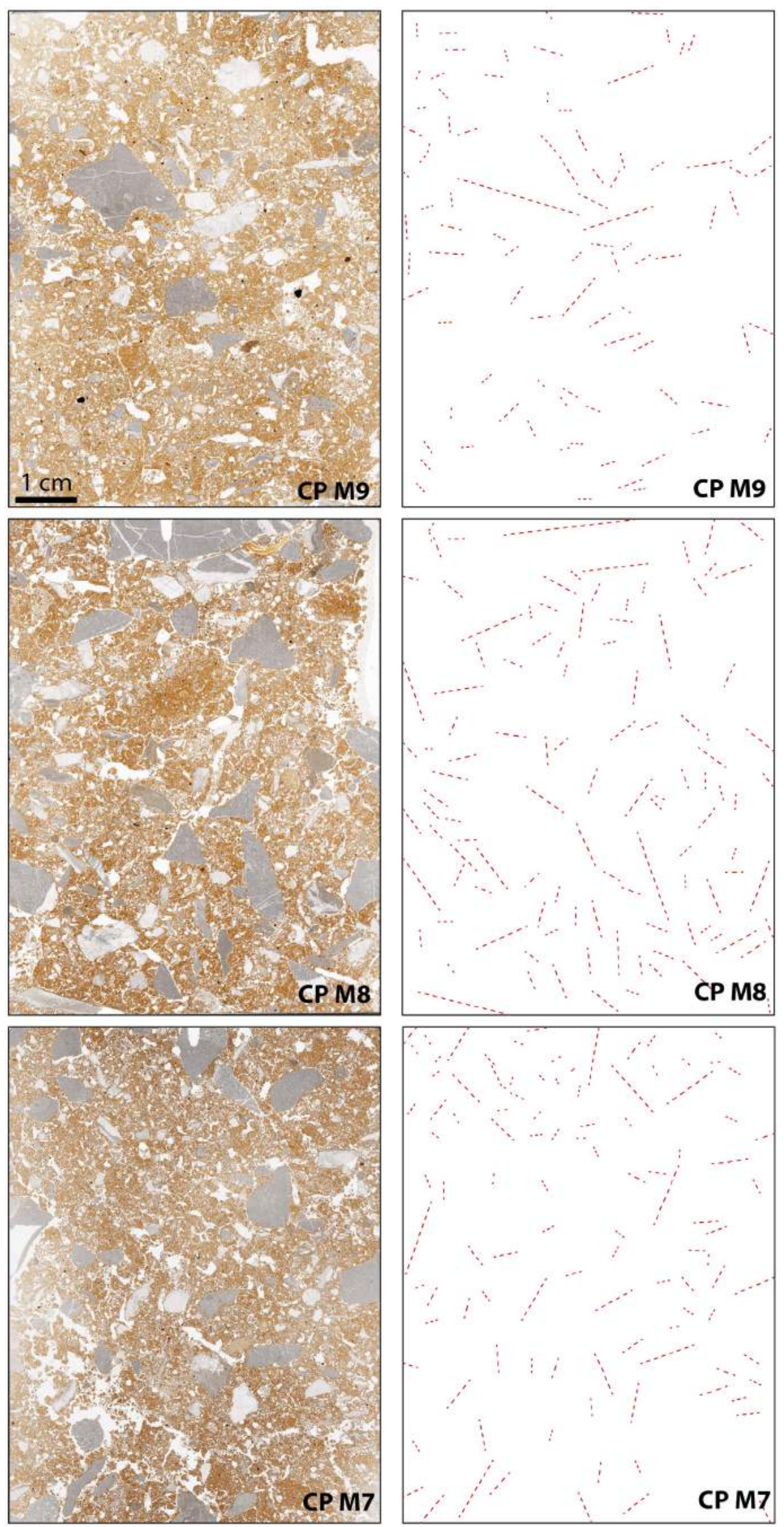

Please cite this article as: Kehl, M., et al., Site formation and chronology of the new Paleolithic site Sima de Las Palomas de Teba, southern Spain, Quaternary Research (2016), http://dx.doi.org/10.1016/j.yqres.2016.01.007 
sample from unit 4 was dated to $9100 \pm 60 \mathrm{cal}$ yr BP $(8152 \pm$ $36{ }^{14} \mathrm{C}$ yr BP; OxA 27985).

\section{IRSL/OSL dating}

The uranium $\left({ }^{238} \mathrm{U}\right)$ and thorium $\left({ }^{232} \mathrm{Th}\right)$ contents of the sediments were calculated by measuring the gamma rays of the corresponding daughter nuclides ${ }^{226} \mathrm{Ra},{ }^{214} \mathrm{~Pb},{ }^{214} \mathrm{Bi}$ and ${ }^{228} \mathrm{Ac}$, ${ }^{212} \mathrm{~Pb}$, ${ }^{208} \mathrm{Tl}$, respectively. For all samples, the specific activity (Bq kg${ }^{-1}$ ) of these nuclides was compared to check for indications of a disequilibrium in the ${ }^{238} \mathrm{U}$ and ${ }^{232} \mathrm{Th}$ decay series. None of the samples showed aberrant behavior; hence, a secular equilibrium was assumed. Initial luminescence measurements on coarse-grained quartz revealed that the quartz OSL signal is close to or already in saturation, with characteristic saturation doses $\left(D_{0}\right)$ of about $45 \mathrm{~Gy}$. Thus equivalent doses could only be obtained by IRSL on coarse-grained feldspar and polymineralic fine grains as well as OSL on fine-grained quartz. To ensure that the OSL on fine-grained quartz is not affected by feldspar contaminants when stimulating with blue LEDs, an additional IR depletion ratio test was applied at the end of each quartz OSL measurement. None of the samples exhibited a discernible luminescence signal during IR stimulation, and IR depletion ratios were all within $10 \%$ of unity (Table 4). Preheat-plateau tests on fine-grained quartz of sample CP7 indicated a decrease of the $D_{\mathrm{e}}$ with increasing preheat temperature, but developed a stable plateau at temperatures between $260^{\circ} \mathrm{C}$ and $300^{\circ} \mathrm{C}$ (Suppl. Fig. S2). Additional DRTs showed that the given dose could be recovered within $10 \%$ from unity for preheat temperatures between $260^{\circ} \mathrm{C}$ and $300^{\circ} \mathrm{C}$ (Suppl. Fig. S2). A preheat/cutheat temperature combination of $280 / 260^{\circ} \mathrm{C}$ was used for paleodose estimation on finegrained quartz. The prior-IR stimulation plateau tests performed on samples CP1, CP3 and CP7 reveal no systematic effect of the first stimulation temperature on $\mathrm{D}_{\mathrm{e}}$ (Suppl. Fig. S3). For all subsequent pIRIR 225 and PIRIR 290 measurements we selected the prior-IR temperature of $50^{\circ} \mathrm{C}$. Further DRTs showed that the applied pIRIR 225 and pIRIR 290 protocols were able to recover the given doses of $67 \mathrm{~Gy}$ (CP4) and $100 \mathrm{~Gy}$ (CP1) on coarse-grained feldspar. Recovery ratios were all within 10\% from unity (Table 3 ). Fading tests on the $\mathrm{IR}_{50}$ feldspar signal revealed mean $g$-values of $3.7 \pm 0.7(\mathrm{CP} 1, \mathrm{n}=11)$ and $3.0 \pm 1.0(\mathrm{CP} 4, \mathrm{n}=$ 11). Considering that after correcting the $I_{50}$ signal for anomalous fading the age estimates of samples CP1 and CP4 are in almost perfect agreement with those obtained from the pIRIR 225 and pIRIR 290 protocols (Table 4), there is strong evidence for stable pIRIR signals with little or no fading. For the pIRIR ${ }_{225}$ and pIRIR ${ }_{290}$ signals we hence did not consider further fading measurements as the commonly observed fading rates of $<2 \% /$ decade of these signals (e.g., Roberts, 2012; Brown et al., 2015; Colarossi et al., 2016) are argued to be laboratory artifacts (Thiel et al., 2011; Buylaert et al., 2012, 2013).

Post-IRIR 225 , PIRIR 290 and IR 50 stimulation of coarse-grain potassium feldspar samples revealed good agreement of the luminescence ages of the lowermost sample CP1. The fine-grain quartz age of the same sample is clearly younger. In contrast, quartz and polymineral fine-grain dating of samples CP2, CP3 and CP7 achieved good age agreement, which further supports that the pIRIR signals are stable. The quartz luminescence signal of sample CP4 was close to saturation; therefore, age determination was concentrated on coarse-grained feldspar, resulting in similar ages using $\mathrm{IR}_{50}$ and $\mathrm{pIRIR}_{225}$ stimulation. Equivalent dose and dose-rate calculation resulted in luminescence ages in the range of 23-48 ka (Table 4).

\section{TL dating}

Heating-plateau tests showed that four of the nine submitted samples have not been heated sufficiently in the past to allow TL dating (data not shown). DRTs suggest that the applied TL SAR protocol is suitable for $D_{e}$ determination of the sample series. Within quoted uncertainty, the given dose could be recovered for three of the four tested samples, and the deviation is $~ 8 \%$ for LP1 (see Table 3 ). Typical glow curves and dose response behavior of TL samples is shown in Figs. S4 and S5 for one aliquot of LP5. Gamma-spectrometry of surrounding material of three OSL samples (Fig. 2, samples 1, 4 and 7) showed the absence of radioactive disequilibria. Luminescence measurement results, analytical data and calculated ages are summarized in Table 5. Ancient heating of artifacts could be determined to the range 48-80 ka. Due to the scatter in ages and no clear layer attribution, a mean age was not calculated.

\section{Lithic assemblages}

In total 357 stratified lithic objects were recorded from the site (Table 6). The collection results from profile cleaning, whereby the stratigraphic position of the findings was documented. It represents a small sample, but nevertheless gives insight into the sequence. Based on stratigraphic analysis of the lithics, a clear concentration appeared within units 9-10. More than 85\% (309 pieces) of all lithic objects originated from these units. Apart from unit 6 with an amount of 9.5\% of lithics, all other units delivered scattered objects only. The absence of lithics in units 7 and 8 is remarkable and marks a clear hiatus in the occupation of the site. Units 3 to 5 brought undiagnostic items, such as singular blanks and debris and a randomly retouched blade fragment, to light.

Geological and lithological characteristics of the surrounding of Guadalteba provide a high variety of siliceous rock (Medianero et al., 2011). From these natural occurrences prehistoric humans from Sima de Las Palomas de Teba made use at any time. Different types of flint were distinguishable. Massif flint (sílex masivos) in different colors, as well as red and gray-black radiolarite, represented the main raw material types. Singular other types were white to cream-colored porous flint (sílex poroso), oolitic flint (sílex oolíticos), striped flint (sílex bandeado) and green radiolarite.

Flaking debris amounted to $29 \%$ of all lithics. This low percentage is probably due to the fact that the assemblages result from profile cleaning and not from a controlled excavation. Despite this reduced interpretative value of the collection, it is worthwhile to present some preliminary results of the lithics assemblage, especially concerning core reduction strategies and formal tools. A first look on the quantitative distribution of cores, blanks, debris and formal tools showed similar features of the lower units 6 and 9-10.

For the reconstruction of the reduction strategies, a total of 12 cores were studied with most cores belonging to lowermost units 9-10. Additionally, 38 blanks-six from unit 6 and 32 from unit 9-10-that feature as technological markers provided further information about the lithic production systems of the Sima de Las Palomas de Teba.

Unit 6

Only a single core and six blanks of unit 6 were suitable as technological markers. Altogether, they resulted from three different corereduction strategies: Levallois recurrent unidirectional convergent, Levallois recurrent centripetal, and Kombewa. The single core that was reduced following the centripetal method showed natural cortex surface with additional preparation on the lower side of the core. The required convexity of the reduction surface was established by centripetal flaking as well as from lateral, via éclats débordants. The striking platform was prepared by a single negative.

Four predetermined blanks from the exploitation stage showed, on their dorsal surface, remains of parallel negatives converging towards the distal end of the blank and therefore form a clear pattern of the Levallois recurrent unidirectional convergent method (Fig. 7, 2-4). On every piece, both lateral negatives shaped a central ridge, which constituted the tip of the elongated triangles. Despite the uniformity of the dorsal pattern, the preparation of the striking platform was implemented in different ways: no preparation (use of cortex), dièdre, rough and fine faceted. 

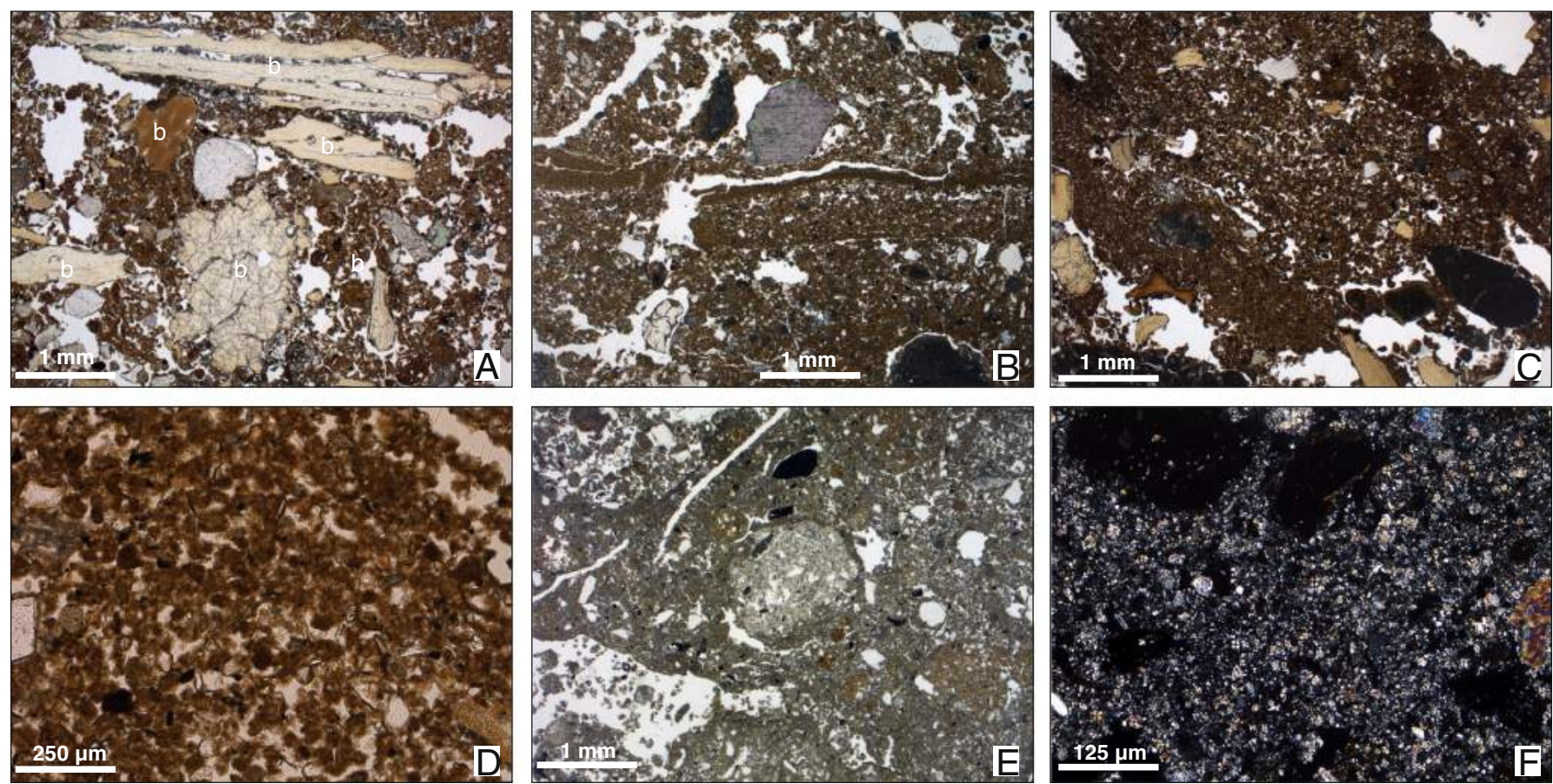

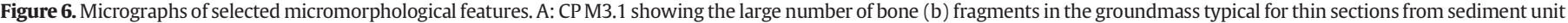

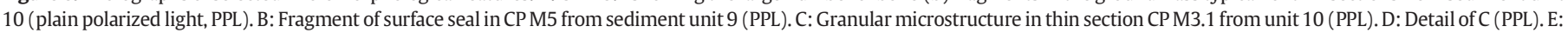

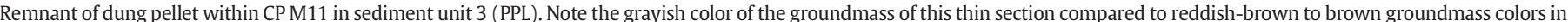

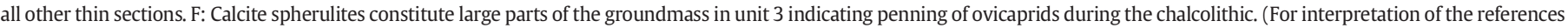
to color in this figure legend, the reader is referred to the web version of this article.)

The opportunistic Kombewa conception was represented by only two flakes. Both used convex ventral surface as reduction surface and their striking platforms were rough faceted. The indications for the character of the applied reduction strategies were poor, and they were even less about the initialization of the raw material. Not one single blank from unit 6 still had cortical surfaces.

Only two formal tools have been detected in the assemblage of unit 6: a simple scraper and a denticulate tool.

\section{Units 9-10}

Within the richest unit of Sima de las Palomas de Teba, diverse Levallois recurrent as well as preferential methods were present. Cores following the Levallois preferential method were relatively abundant (Fig. 7, 5-7). The lower surfaces of the three cores were generally covered by natural surfaces with singular preparation negatives. The distal convexity was configured by distal preparation. Lateral convexity occurred by natural cortex or was generated through lateral preparation. The striking platform showed both rough and fine preparation. Ten predetermined flakes represented the exploitation stage. Their striking platforms showed different characteristics: single negative, dièdre, rough and fine faceted.

The Levallois recurrent method of unit 9-10 occurred as unidirectional, centripetal, unidirectional convergent and bidirectional version. Although the lower surface of one core was covered with ventral surface and without any preparation, it represents the Levallois recurrent unidirectional method. Distal and lateral convexity was maintained by distal and lateral preparation and the striking platform roughly prepared. Two associated predetermined blanks documented the exploitation stage: an outrepassé represented the re-initialization stage.

Cores reduced following the Levallois recurrent centripetal method were missing, whereas blanks from the appropriate exploitation stage were well present. Eleven predetermined flakes provided centripetal dorsal pattern and different kinds of striking platform preparation: single negative, cortex, dièdre and fine faceted. The re-initialization stage was represented by one single éclat débordant.
The remaining recurrent methods-unidirectional convergent (Fig. 7,1 ) and bidirectional-were merely presented by a single predetermined blank, respectively. Their striking platform was either fine faceted (unidirectional convergent) or covered by a single negative (bidirectional). In addition to the described methods, the Kombewa core reduction strategy which makes ad hoc use of naturally-given conditions was documented within units 9-10. A single core, as well as a Kombewa flake, was found.

Six opportunistic reduced cores without any detectable strategy completed the lithic reduction strategy of units 9-10.

Whereas no cortical surface was found in the assemblage of unit 6 , units 9-10 revealed ten blanks, which give an indication for the initialization of raw material nodules on-site.

Eight simple scrapers and nine denticulate tools comprised the little inventory of formal tools of units 9-10.

\section{Discussion}

\section{Stratigraphy and site formation}

Sediment units 10 and 9 at the base of the sequence contain abundant Mousterian artifacts, bone and charcoal fragments and probably represent undisturbed archeological layers in the sense of Courty (2001). This is indicated by several micromorphological features. First, the amount of bone fragments and burnt materials is very high in thin sections from units 9 and 10, whereas all other thin sections contain very small amounts of these archeologically relevant materials. Second, the presence of internal sediment boundaries and microstratification, i.e. the vertical alternation of different materials in distinct microlayers within the same level is observed in thin sections from units 9 and 10 only. Dwelling in a cave by humans involves dropping of different materials on the occupation surface and differential compaction due to trampling, both causing microstratification. Post-depositional mixing by lateral transport, strong bioturbation, frost action or rake-out of materials would destroy or at least displace microstratified materials. This 
Table 2

Micromorphological descriptions of sediment units.

\begin{tabular}{l}
$\begin{array}{l}\text { Sediment Thin section Description } \\
\text { unit }\end{array}$ \\
\hline
\end{tabular}

unit

$3 \quad$ CP M11

4 to $6 \quad$ CP M10 CP M9, CP M8, CP M7

The thin section shows a stony light brown silty loam with reddish brown granules of medium to coarse sand size. The fine fraction has a light yellow brown color and mostly consists of calcite grains either occurring as small aggregates of microsparite and micrite crystals or as calcite spherulites. It is likely, that most of the silt-size calcite grains are weakly preserved calcite spherulites as well. Comparatively few quartz and other siliclastic grains are present. Phytoliths are found scattered throughout the groundmass. The mostly calcitic groundmass is significantly different from the calcite-depleted one of other thin sections. The calcite spherulites are often concentrated in clusters and associated with phytoliths indicating that they are related to animal droppings of ruminants, probably ovicaprids. Very locally, ellipsoid structures resembling dung pellets are preserved. Fresh organic matter in these pellets is lacking, which may be explained by its degradation through insects, microbial turnover or burning. Many large burrows partly filled with small organo-mineral granules of insect excrements, and low packing density suggest strong bioturbation by insects such as beetles. Few pieces of charcoal and small bone were found. Phosphatic features are very rare. Among the pedofeatures, a significant number of micritic hypocoatings around biochannels is noticeable. These hypocoatings and channels are characteristic features related to fine plant roots and their comparatively high frequency is due to the proximity of unit 3 to the modern soil with high density of roots.

The thin sections are similar in structure and composition. They display dark brown to reddish brown silty loams with high contents of angular to sub-rounded limestone fragments, which mostly occur in chaotic arrangement and apparently floating within the clayey to silty matrix. Thin section CP M9 shows weak horizontal alignment of elongated fragments. Thin section CP M10 from the top of unit 4 showed a more clearly developed subangular blocky structure and slightly darker groundmass. In comparison to thin sections CP M9 to CP M7, the sample CP M10 is characterized by more strongly expressed bioturbation features and more intense staining by organic matter. Sample CP M8 contains comparatively large amounts of microsparitic calcite infillings. It is not clear, whether these represent ash calcite or were derived from precipitation of secondary calcite from the vapor phase. Other indicators of fire such as charcoal are very rare. Burnt bone is missing. In all thin sections, very few if any pieces of flint, and few and mainly small bone fragments were found. Anorthic phosphate nodules, representing bird or bat droppings, occur in traces. The packing density is low and no clear signs of compaction, e.g. caused by trampling, are evident.

This thin section was taken from the archeologically sterile layer. It does not display pronounced differences in sediment structure compared to thin sections CP M7 to M10 from the overlying units. Archeologically relevant materials occur in very lower numbers and consist of several small $(<1.5 \mathrm{~mm}$ in length) flakes of flint and very few small charcoal pieces. These materials could have been mixed into the sediment by burrowing animals. Differences in weathering degree between sediment from units 7 and 4 to 6 are not apparent under the microscope.

This sediment unit contains more artifacts than the overlying archeologically sterile unit 7 but less than underlying unit 10. The reddish brown groundmass of thin section CP M5 represents the upper part of unit 9 and shows a moderately well developed subangular blocky microstructure. CP M2 taken from the lower part of the unit has a slightly lighter color and a chamber and burrow microstructure. Both sections contain discontinuous laminations of silt and clay, partly with vesicular pores occurring underneath the densely packed clay-rich layer. These laminations are fragments of sedimentary seals (Pagliai and Stoops, 2010), which form by deposition from lateral flow at the surface of sediments or soils. The degree of compaction is moderate. The extent of bioturbated zones is less than in overlying deposits. Flint and charcoal pieces are sparse, but some larger bone fragments occur and burned bone is more frequent. In CP M5, microsparitic calcite infillings (or ash?) are common, for instance surrounding a large bone fragment at the base of the section.

10 CP M4.1, СР M4.2, СР M1a,b CP M3.1,

All sections from this unit are rich in angular bone fragments, moderately rounded bone sand, burnt bone, flint and charcoal. In thin sections CP M3.1 to 3.3 as well as CP M4.1 and CP M4.2, preferential orientation of archeological materials and rock fragments along with a high content of crushed bone suggests compaction of the sediment by trampling. This assumption is supported by the presence of compacted zones of fine-grained sediment, which form internal boundaries within the deposit. Thin sections CP M1a and b are less strongly compacted and do not show preferential alignment. Probably, packing density decreased because of bioturbation, which is reflected by frequent burrows and granules resembling organo-mineral excrements of soil mesofauna. A conspicuous feature is the granular microstructure within unit 10 (Fig. 6C, D). Most of fine particles occur as brown granules, 50 to $100 \mu \mathrm{m}$ in diameter. These locally coalesce to form larger subangular blocky aggregates. The granules probably represent organo-mineral excrements of mesofauna such as collemboles. Fragments of sedimentary seals are another feature of unit 10. The thin sections do not show features of an in-situ fireplace such as intercalations of charcoal- or ash rich layers or burned soil.

\section{Table 3}

Dose recovery test (DRT) results of OSL and TL samples from Las Palomas. $\mathrm{n}$ denotes the number of measured aliquots (all were accepted). The natural OSL signal of fine grain quartz samples was removed by blue stimulation for $40 \mathrm{~s}$ at room temperature. The feldspar samples were bleached for $4 \mathrm{~h}$ in a Hönle SOL2 solar simulator. A residual dose of 1.2 $\mathrm{Gy}$, determined on separate aliquots after $4 \mathrm{~h}$ bleaching, was subtracted from the recovered pIRIR doses.

\begin{tabular}{|c|c|c|c|c|c|}
\hline Sample & Protocol & $n$ & $\begin{array}{l}\text { Given dose } \\
{[G y]}\end{array}$ & $\begin{array}{l}\text { Recovered dose } \\
{[G y]}\end{array}$ & $\begin{array}{l}\text { Ratio } \\
\text { (measured/given) }\end{array}$ \\
\hline CP1 & pIR-IRSL 225 & 5 & 100 & $97.5 \pm 5.1$ & $0.97 \pm 0.03$ \\
\hline CP1 & Quartz OSL & 3 & 92 & $95.7 \pm 5.4$ & $1.04 \pm 0.04$ \\
\hline $\mathrm{CP} 2$ & Quartz OSL & 3 & 151 & $151.8 \pm 9.2$ & $1.01 \pm 0.03$ \\
\hline CP3 & Quartz OSL & 8 & 105 & $109.3 \pm 5.8$ & $1.04 \pm 0.01$ \\
\hline $\mathrm{CP} 4$ & pIR-IRSL 225 & 5 & 67 & $67.9 \pm 3.6$ & $1.01 \pm 0.02$ \\
\hline CP7 & Quartz OSL & 8 & 41 & $44.1 \pm 2.3$ & $1.08 \pm 0.01$ \\
\hline LP1 & TL SAR & 6 & 40 & $43.4 \pm 1.1$ & $1.09 \pm 0.01$ \\
\hline LP4 & TL SAR & 6 & 40 & $40.7 \pm 0.9$ & $1.02 \pm 0.01$ \\
\hline LP5 & TL SAR & 1 & 40 & $42.0 \pm 2.6$ & $1.05 \pm 0.01$ \\
\hline LP7 & TL SAR & 6 & 40 & $40.4 \pm 0.9$ & $1.01 \pm 0.01$ \\
\hline
\end{tabular}

will also be the case with depositional or structural crusts, which typically form at the land surface due to raindrop impact or sheet flow (Pagliai and Stoops, 2010). These represent special forms of microstratification, which are still preserved in sediment units 9 and 10 of the Sima. Differential compaction observed in units 10 and 9 is likely related to trampling. This process is also indicated by the very large number of small bone pieces in thin sections from unit 10 which derive from crushing, often observed in archeological sites with bone or shell (e.g., Goldberg et al., 2009; Miller et al., 2009; Linstädter and Kehl, 2012; Estévez et al., 2014).

Third, it appears likely that the long axes of elongate fragments such as bone, lithic artifacts or limestone grit were deposited parallel to former occupation surfaces resulting in planar orientation of elongated elements. If in thin section several elongate fragments are observed with parallel orientation of their long axes, these particles may occur in planar, linear or imbricated orientation (Lenoble and Bertran, 2004). The fabric type cannot be determined using the 2D-image of a thin section, but the impregnated negatives of the thin section provide two additional 2D-images, which can be put together to estimate fabric 
Table 4

Results of gamma spectrometry, dose rate calculation, equivalent dose $\left(D_{\mathrm{e}}\right)$ measurements and age estimation for sediment burial. All values are shown with their 1 sigma-error. IRSL50 age estimates are corrected for anomalous fading.

$\begin{array}{llllllllllllll}\text { Lab. } & \text { Sample } & \text { Grain } & \text { Protocol } & \text { Water } & \text { Depth } & \mathrm{U}[\mathrm{ppm}] & \mathrm{Th}[\mathrm{ppm}] & \mathrm{K}[\%] & n^{\mathrm{a}} & \text { OD } & \text { IR } & \dot{D}_{\text {internal }} & \dot{D}_{\text {ext }}[\mathrm{Gy} \text { ka }\end{array}$

code size content $[\mathrm{m}]$

$[\mu \mathrm{m}] \quad[\mathrm{wt} \%] \quad$ ratio $\mathrm{ka}^{-1}$

$\frac{\mathrm{a}^{-1} \mathrm{l}}{\beta} \frac{}{\alpha}$

$\begin{array}{lll}\alpha & \beta\end{array}$

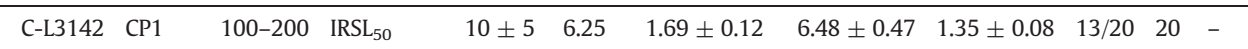

$0.68 \pm 0.07 \pm 0.02 \quad 1.21 \pm 0.08 \quad 0.74 \pm 0.04 \quad 0.045 \pm 0.005 \quad 2.75 \pm 0.11 \quad 91.9 \pm 6.8 \quad 48.4 \pm 6.3$

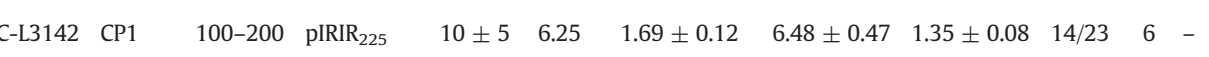

$\begin{array}{llllllll}0.06 & & & & & & & \\ 0.68 & 0.07 \pm 0.02 & 1.21 \pm 0.08 & 0.74 \pm 0.04 & 0.045 \pm 0.005 & 2.75 \pm 0.11 & 125.9 \pm 6.7 & 45.9 \pm 3.4\end{array}$

0.06

$\begin{array}{llllllllll}\text { C-L3142 CP1 } & 100-200 & \text { pIRIR }_{290} & 10 \pm 5 & 6.25 & 1.69 \pm 0.12 & 6.48 \pm 0.47 & 1.35 \pm 0.08 & 13 / 19 & 19\end{array}$

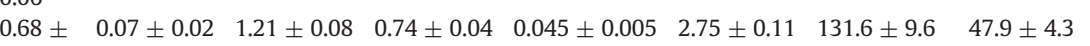

0.06

$\begin{array}{lllllllllll}\text { C-L3142 CP1 } & 4-11 & \text { Quartz OSL } & 10 \pm 5 & 6.25 & 1.69 \pm 0.12 & 6.48 \pm 0.47 & 1.35 \pm 0.08 & 10 / 10 & 0 & 0.98 \pm\end{array}$

0.02

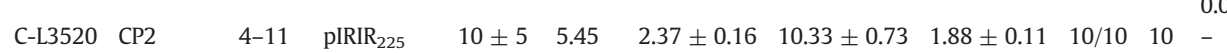

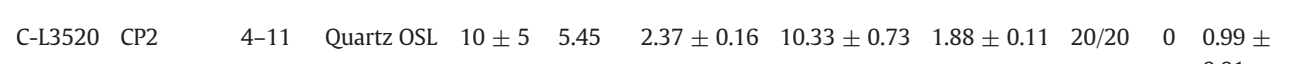

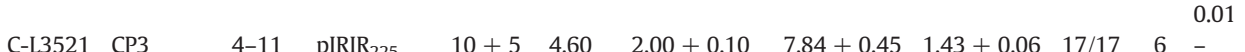

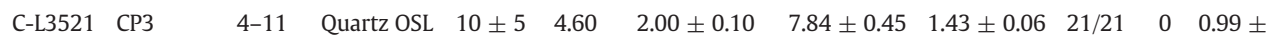

$\begin{array}{llllllllll}\text { C-L3521 CP3 } & 4-11 & \text { Quartz OSL } & 10 \pm 5 & 4.60 & 2.00 \pm 0.10 & 7.84 \pm 0.45 & 1.43 \pm 0.06 & 21 / 21 & 0.99 \pm \\ & & & \end{array}$

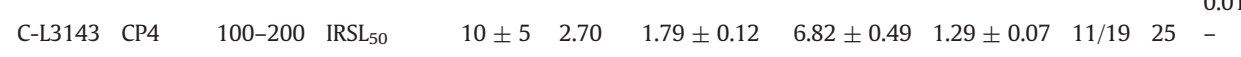

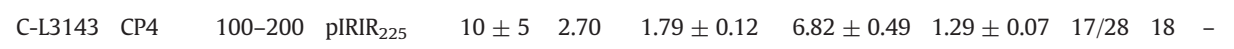

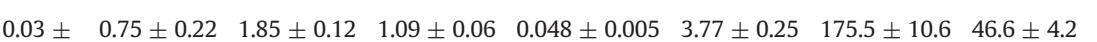
0.003

$\begin{array}{lllllllllll}\text { C-L3368 } & \text { CP7 } & 4-11 & \text { pIRIR }_{225} & 10 \pm 5 & 1.55 & 1.52 \pm 0.10 & 5.18 \pm 0.35 & 0.88 \pm 0.05 & 5 / 5 & 0\end{array}$

$\begin{array}{llllllll}0.03 \pm & 0.59 \pm 0.17 & 1.43 \pm 0.08 & 0.85 \pm 0.04 & 0.051 \pm 0.005 & 2.96 \pm 0.19 & 119.9 \pm 6.2 & 40.5 \pm 3.4\end{array}$ 0.003

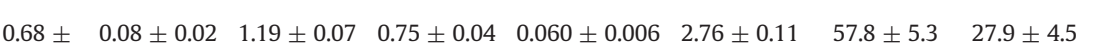
0.06

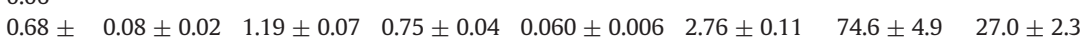

0.06

$0.03 \pm \quad 0.42 \pm 0.12 \quad 0.92 \pm 0.05 \quad 0.57 \pm 0.03 \quad 0.066 \pm 0.007 \quad 2.01 \pm 0.14 \quad 50.4 \pm 2.6 \quad 25.1 \pm 2.2$

0.003

$\begin{array}{lllllllllll}\text { C-L3368 } & \text { CP7 } & 4-11 & \text { pIRIR }_{290} & 10 \pm 5 & 1.55 & 1.52 \pm 0.10 & 5.18 \pm 0.35 & 0.88 \pm 0.05 & 9 / 9 & 0\end{array}$

$\begin{array}{llllllll}0.03 \pm & 0.42 \pm 0.12 & 0.92 \pm 0.05 & 0.57 \pm 0.03 & 0.066 \pm 0.007 & 2.01 \pm 0.14 & 51.6 \pm 2.6 & 25.7 \pm 2.2\end{array}$ 0.003

$\begin{array}{lllllllllll}\text { C-L3368 CP7 } & 4-11 & \text { Quartz OSL } & 10 \pm 5 & 1.55 & 1.52 \pm 0.10 & 5.18 \pm 0.35 & 0.88 \pm 0.05 & 22 / 22 & 0 & 1.03 \pm\end{array}$

${ }^{\mathrm{a}}$ Number of accepted in relation to measured aliquots. 


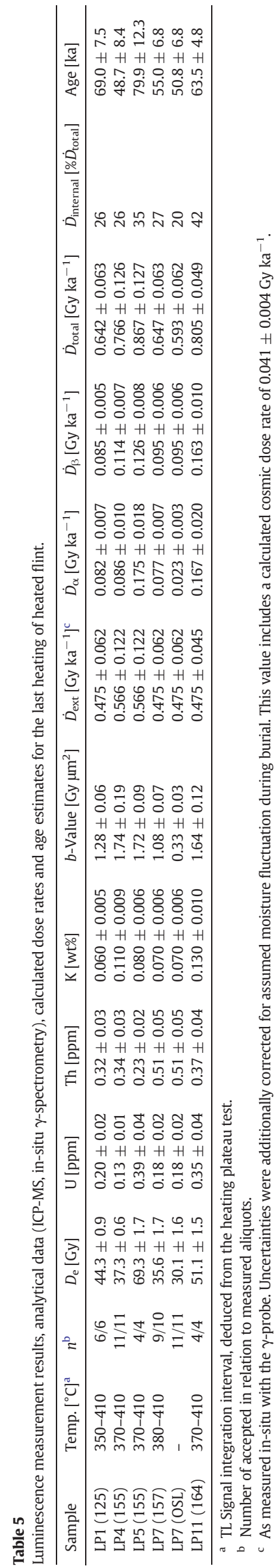

Table 6

Stratigraphical distribution of lithics at Sima de Las Palomas de Teba.

\begin{tabular}{llllll}
\hline Unit & Core & Blank & Debris & Formal tools & Total \\
\hline 3 & - & 1 & 1 & 1 & 3 \\
4 & - & 5 & 2 & - & 7 \\
5 & - & 3 & 1 & - & 4 \\
6 & 1 & 21 & 10 & 2 & 34 \\
$7-8$ & - & - & - & - & - \\
$9-10$ & 11 & 191 & 90 & 17 & 309 \\
\hline Total & $12(3.3 \%)$ & $223(62.1 \%)$ & $104(29.0 \%)$ & $20(5.6 \%)$ & 359 \\
\hline
\end{tabular}

type. Preferential orientation of elongate fragments is more strongly expressed in thin sections and impregnated blocks of units 10 and 9 than in all other thin sections and planar fabric is the most probable, whereas random fabric was observed for thin sections from units 7 to 4. However, preferential orientation of elongate clasts may result from deposition by overland flow or lateral soil creep. In both cases, elongate grains show an oblique orientation inclined towards the direction of flow (Bertran and Texier, 1999; Mücher et al., 2010). This feature and other indicators of fluvial action such as graded bedding or erosional surfaces were not observed during preparation and sampling of the profile within the Sima. It appears highly unlikely that high-energy flow of water, which would be needed to transport and align rock fragments or other elongate particles, affected the sequence neither during accumulation of units 10 and 9 nor afterwards.

In units 10 and 9 post-depositional alteration is mainly related to weak bioturbation, and possibly dissolution and/or re-crystallization of ash calcite. A comparatively high magnetic susceptibility could be related to heating in the vicinity of hearths. Overall, units 10 and 9 have distinct geochemical signatures, which point to a change in sediment source and/or reduced anthropogenic input during accumulation of unit 9.

Large blocks within unit 8 derived from partial roof collapse. Another phase of increased roof fall is probably represented by unit 2. Roof spalling contributed significant amounts of limestone fragments in all units.

After the roof collapse of unit 8, the sediments of unit 7 accumulated, which are apparently very poor in artifacts suggesting a period of normal deposition. The sediment shows higher $\mathrm{K} / \mathrm{Rb}$ ratios than over- and underlying units, interpreted as reflecting decreased weathering intensity during accumulation of unit 7. However, this trend is not shown by other geochemical ratios including $\mathrm{Na} / \mathrm{Al}, \mathrm{Ca} / \mathrm{Si}$, or $\mathrm{Sr} / \mathrm{Ba}$ (data not shown), which may suggest lithological changes not related to weathering. Median grain size, $\mathrm{L}^{*}$-value, $\mathrm{P}$ content as well as the $\mathrm{Fe} / \mathrm{Ti}$ ratio delineate a sharp boundary towards unit 6 . Unit 7 thus forms a distinct geological layer with very poor if any signs of occupation.

Unit 7 closely resembles sediments of units 6 to 4 in respect to random arrangements of rock fragments, comparatively low packing density and lack of microstratigraphic features such as internal layering or fragments of surface seals. Macroscopic inspection shows that clast orientation is very rare and locally restricted. The micromorphological features share many properties with poorly sorted porphyric material encountered in slope deposits (Bertran and Texier, 1999). The combination of these observations suggests that the sediment was deposited mainly by natural processes. Fast lateral movement during landslides or debris flows is unlikely, because this would have left behind more heterogeneous deposits and macroscopic or microscopic rotational deformation structures (Phillips, 2006; Mücher et al., 2010; Karkanas et al., 2015). These features were not observed in the profile and thin sections of the Sima. Slow processes of mass movement, such as soil creep along a former slope inclined towards the interior of the Sima in combination with spalling of limestone fragments, appear more likely.

The boundaries between sediment units 6 to 4 are gradual as suggested by field observation and sedimentological parameters. Weak differences in structure and composition displayed by thin 


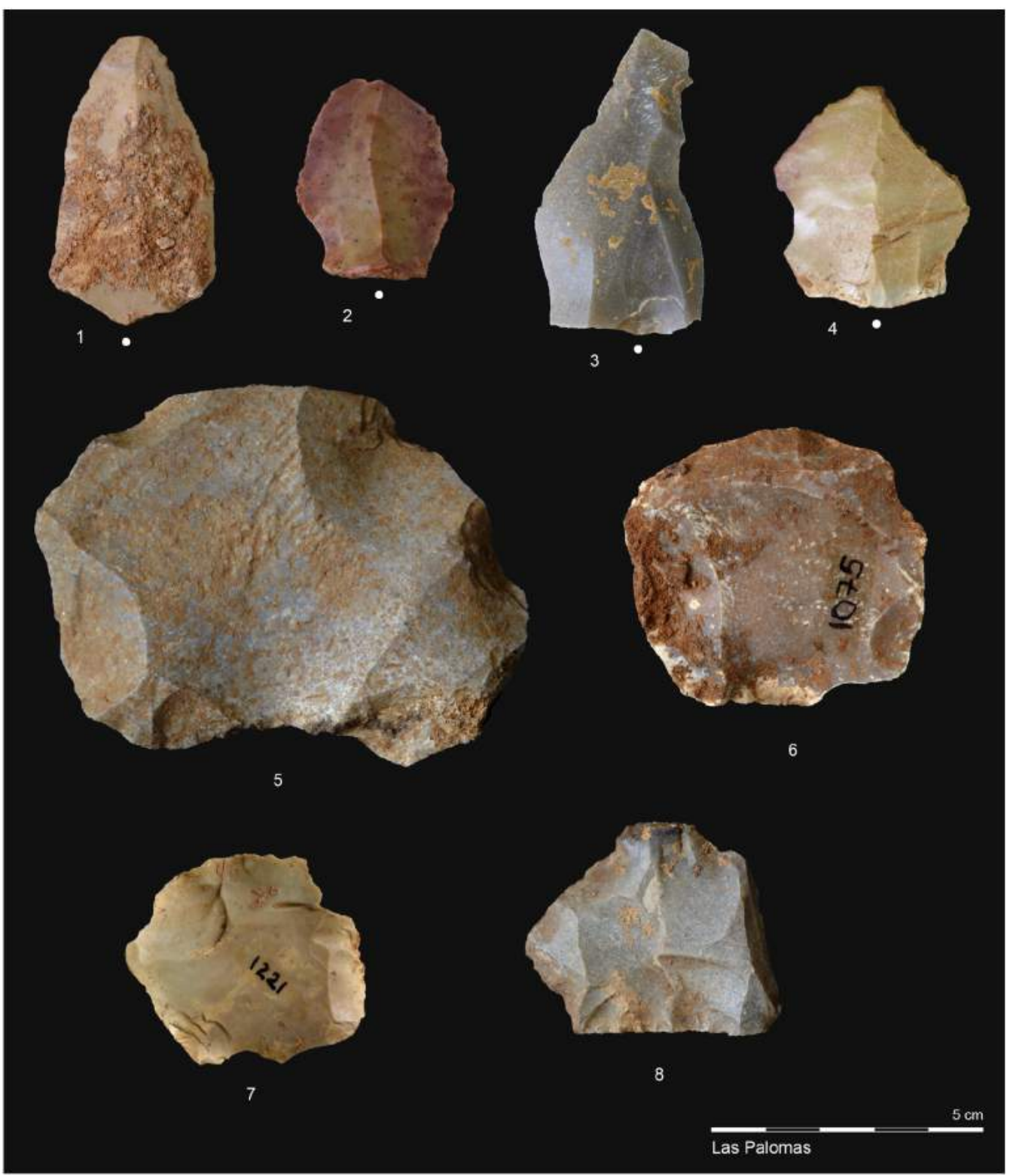

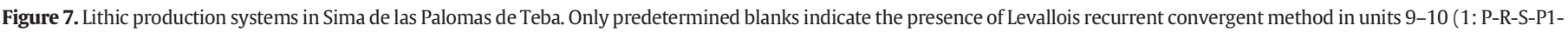

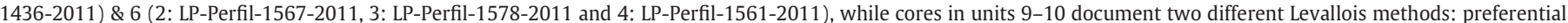

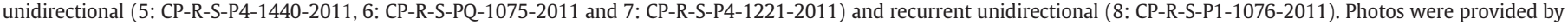
Javier Medianero Soto.

sections from units 6 to 4 corroborate this finding. The scattered distribution of artifacts, the absence of depositional features such as preferential alignment of elongate clasts or microstratification and the low degree of compaction suggest that archeological materials are not preserved in undisturbed layers. Instead, the units probably represent laterally transported hence reworked packages of artifact bearing sediments. The primary place of occupation was probably located farther outside of the rock shelter. Therefore, the time of sediment deposition and burial may considerably postdate the production and use of dispersed artifacts.

Sediment unit 3 had a sharp lower boundary towards unit 4, was more silty, and had highest $\mathrm{L}^{*}$-values. Lithic artifacts were not recovered but the unit contained a fragment of a human mandible. The thin section from this layer showed characteristic calcite spherulites in the groundmass and abundant calcite grains of medium silt size $(\sim 10$ $20 \mu \mathrm{m}$ in diameter), as well as remnants of herbivore dung (Fig. 6E, F). Calcite spherulites are known to form in the guts of ruminants (e.g., Canti, 1999; Brochier, 2002) and may be taken as evidence for the presence of ovicaprids in shelters (e.g., Linstädter and Kehl, 2012). Their presence in sediment unit 3 together with phytoliths and pellet structures indicate the penning of ovicaprids in the Sima during the Chalcolithic. The large amount of microsparitic calcite crystals in the groundmass possibly represent degraded spherulites. The Holocene deposits of unit 3 thus unconformably rest on the Pleistocene sequence. Variation in sedimentological parameters within this unit indicates a further subdivision, which may be unraveled during excavation.

\section{Chronology}

Whenever possible, quartz and feldspar minerals of different grain sizes as well as different measurement techniques for internal crosscheck were used for luminescence dating. An age discrepancy between coarse-grained feldspar and fine-grained quartz ages was observed for the lowermost sample CP1 (Fig. 8). However, the quartz samples did not show any unusual luminescence characteristics, and hence the relative age underestimation cannot be explained so far. Equally, it cannot 
be excluded that the feldspar ages were overestimated due to incomplete resetting of the signal during sediment transport. This might not have affected the quartz sample because the blue stimulated OSL signal resets much faster than IR and pIRIR stimulated luminescence signals (Buylaert et al., 2012; Murray et al., 2012). However, the discrepancy of the four ages of sample CP1 is not severe, and all four ages passed a homogeneity test with $\mathrm{p}=0.20$ (Galbraith, 2003), which indicates that all ages represent the same sedimentological event. For all other samples, age estimates on different minerals, grain sizes and signal stimulation agree with each other, which supports the reliability of the IRSL/OSL ages.

While no direct comparison could be drawn between additive-dose and regenerative-dose protocols, results of the dose recovery tests (DRT) indicate accurate dose estimates of heated flint samples. Certainly, there could have been undetected sensitivity changes during the first heating in the laboratory, but the trend of observed sensitivity changes during the SAR cycles renders this scenario unlikely. Furthermore, the SAR protocol appeared to be the only way to date the small-sized artifacts. Low concentrations of $\mathrm{K}$, Th and $\mathrm{U}$ within the flint reduce the percentage of internal dose rate to total dose rate to $21-43 \%$. Since the external dose rate plays the dominant role, its inexact estimationrelated to unknown past moisture contents and potentially nonrepresentative in-situ measurements-leads to increased $1 \sigma$ uncertainties of determined ages. One reason for the spread in ages may thus be heterogeneities in environmental dose rates that could not be fully accounted for.

Ages are not in stratigraphic order, although overlapping within uncertainties, with sample LP5 showing the highest age ( $80 \pm 12 \mathrm{ka})$. This is peculiar, since this sample was obviously found at the same spot as LP4 which yields an age $\sim 30$ ka younger. Conceivable scenarios for this discrepancy may be (1) wrong allocation of one of the finds (LP4, LP5) during profile cleaning or afterwards, (2) relocation of one sample within the profile, or (3) incomplete ancient heating of LP5. At present, none of these hypotheses can be ruled out. All artifact ages are systematically older than the bracketing OSL sediment ages (CP1, CP2). Since both methods address different events (ancient heating vs. last light exposure), the discrepancy of their results as well as differing ages of LP4 and LP5 would support the hypothesis of post-

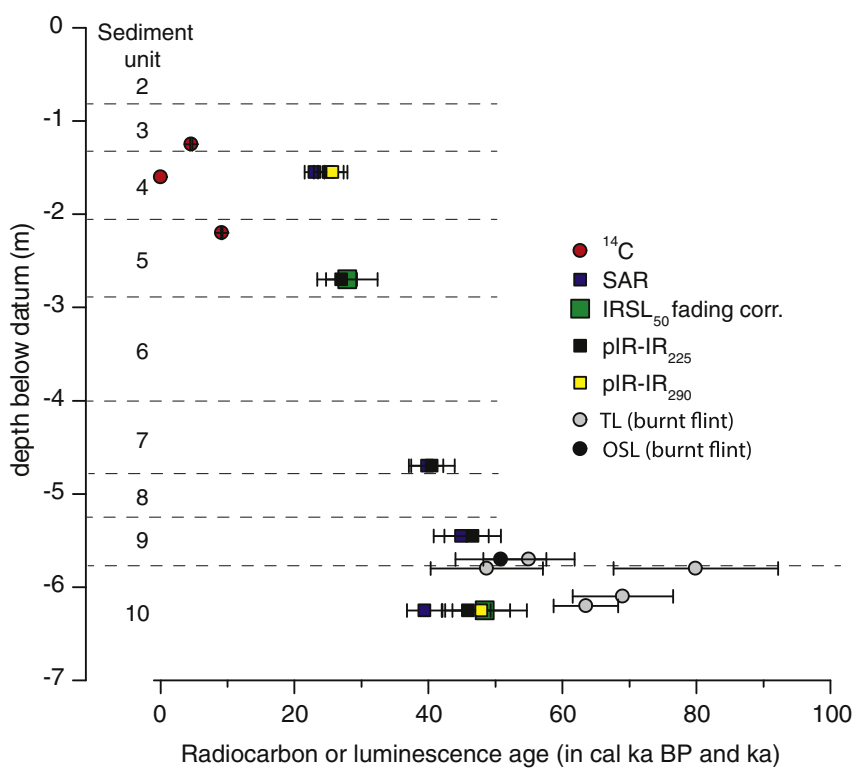

Figure 8. Results of chronological dating for the profile at Sima de Las Palomas de Teba. Luminescence age estimates are shown with 1-sigma error. The conventional radiocarbon dates were calibrated using OxCal, vs. 4.2.2 (Bronk Ramsey, 2013). The 95.4\% probability interval is 4784 to 4417 cal yr BP for the tooth sample (COL2013.1.1) and 9250 to $9008 \mathrm{cal} \mathrm{yr} \mathrm{BP}$ for the charcoal sample (OxA-27985). depositional relocation (e.g., bioturbation) within the Sima, although contradicting micromorphological analysis. These TL/OSL ages provide a first indication for the time of occupation, but further and more accurate artifact dating in the course of upcoming excavations is required.

Another chronological problem are age inversions between the radiocarbon dates on bone (OxA 27961) and charcoal (OxA 27985) from unit 4 and 5 , respectively, and the luminescence age estimates for the uppermost sample CP7 (Fig. 8). It appears likely that while collecting the charcoal from the surface of the profile, recently reworked material has been sampled. The modern age for the bone sample can be explained in this way. It is also likely that the young age of the charcoal sample does not date the sedimentary context and has to be taken as erroneous. The age of the maxillar fragment, however, is reliable, because the sedimentary disconformity between unit 4 and unit 3 is obvious and sediment properties of unit 3 including the presence of calcite spherulites and dung pellets strongly indicate penning of ovicaprids, which is in accordance with a Chalcolithic occupation. This date suggests a long depositional hiatus after accumulation of the uppermost layer of unit 4 , yielding age estimates of at least $23 \pm 1.5 \mathrm{ka}$ (quartz OSL).

\section{Human occupation}

As discussed above, micromorphological features suggest that units 9 and 10 represent undisturbed archeological levels. These contain a fair sample of Levallois Mousterian artifacts, which are well represented in this region of southern Spain (Vallespí, 1986; Barroso and De Lumley, 2006; Cortés, 2011; Ramos, 2013). Within the Sima a limited range of different core reduction concepts and methods is identified. Besides the Levallois preferential unidirectional method, different recurrent Levallois methods (unidirectional, bidirectional and centripetal) represent the hierarchical structured conceptions. Additionally, opportunistically reduced cores, including Kombewa cores, are observed. Despite the unequal quantity of lithic remains, the technological homogeneity of the units studied is remarkable. Volumetric conceptions, such as discoidal as well as blade/bladelet cores, are absent. In units 6 and 9-10 predetermined blanks as well as cores represent the exploitation stage of the reduction sequences which took place on-site. Indications for the re-initialization on-site exist only in units 9-10. Finally, neither in unit 6 nor in units $9-10$ have indications for initialization stage turned up so far. This fits with the low presence of cortical blanks, and therefore the initialization of the raw material probably took place outside of the area studied so far of Sima de las Palomas de Teba.

The intensity of occupation in this part of the rock shelter apparently decreased with time, since the abundance of artifacts, bone fragments and charcoal is decreasing towards the top of unit 9 (Fig. 2). Occupation probably stopped after partial roof collapse (unit 8). Luminescence age estimates for sample CP3 taken from above the roof fall yielded $39.8 \pm 2.4 \mathrm{ka}$ (quartz OSL) and $40.5 \pm 3.4 \mathrm{ka}\left(\right.$ pIRIR $\left._{225}\right)$, providing a terminus ante quem for this occupation. The quartz age estimate of $39.4 \pm$ $2.6 \mathrm{ka}$ (quartz OSL) for sample CP1 from unit 10 correlates with radiocarbon ages for the uppermost Neanderthal occupation of Level 8 at Gruta de Oliveira (Angelucci and Zilhão, 2009). The IRSL luminescence age estimates of this unit point to an earlier occupation not later than $44.9 \pm 4.1 \mathrm{ka}$ (sample CP 2, quartz OSL). Overall, the units 9 and 10 chronologically roughly fit with data reported from other sites of Late Neanderthal occupation in Southern Iberia including El Bajondillo (Cortéz-Sánchez et al., 2008), Boquete de Zafarraya (Wood et al., 2013), El Salt (Galván et al., 2014) or Gorham's cave (Pettitt and Bailey, 2000). Our data do not corroborate the findings for a prolonged Neanderthal survival in the south, as claimed by Hublin et al. (1995), Finlayson et al. (2006), or Fernández et al. (2007).

The rare pieces of microdebris, charcoal and bone detected under the microscope within unit 7 probably invaded the sediment by bioturbation. It is very likely that accumulation of unit 7 took place while this part of the rock shelter was not occupied. Towards the top of the sequence, sediment unit 6 contains a comparatively large number of lithics of clearly 
Mousterian affinity, but the pieces are scattered and macroscopic and microscopic features indicative of an undisturbed archeological layer are lacking. This second Middle Paleolithic occupation event lacks absolute dating. It is bracketed by luminescence age estimates for samples CP3 (unit 7) and CP4 (unit 5), i.e. between $39.8 \pm 2.4 \mathrm{ka}$ (quartz OSL) or $40.5 \pm 3.4 \mathrm{ka}\left(\mathrm{pIRIR}_{225}\right)$ and $27.0 \pm 2.3 \mathrm{ka}\left(\mathrm{pIRIR}_{225}\right)$ or $27.9 \pm 4.5 \mathrm{ka}$ (fading corrected $\mathrm{IRSL}_{50}$ ), respectively. The sample CP4 stems from the lower part of unit 5, which provides an Upper Paleolithic chronology, similar to sample CP7, which dates unit 4 to $25.7 \pm 2.2 \mathrm{ka}\left(\mathrm{pIRIR}_{290}\right.$ ) and $23.0 \pm 1.5 \mathrm{ka}$ (quartz OSL). Unfortunately, both units yielded undiagnostic lithic assemblages only. They might belong to yet unclear Upper Paleolithic occupations in the Sima.

OSL dating gives evidence that the accumulation of unit 6 took place sometime after $\sim 40 \mathrm{ka}$. This recent time appears to corroborate the results of uranium series datings for Level 8 in Gruta de Oliveira (Hoffmann et al., 2013) suggesting a later survival of $\mathrm{Ne}$ anderthals. However, sediment deposition dated by the luminescence method applied here may not necessarily correlate with the time of lithic production. Field evidence and micromorphological results rather point to reworking processes. Hence, unit 6 could have accumulated after the production of the enclosed artifacts. Considering this evidence, we suggest to use the more reliable age estimates for unit 9 of about $40 \mathrm{ka}$ as chronological estimate for the end of the Middle Paleolithic at the Sima de las Palomas de Teba.

Significant reduction of occupation density and inconsistent dating of late Neanderthal occupations is a well-known phenomenon in southern Iberia (Schmidt et al., 2012; Wood et al., 2013). The possibility of Upper Paleolithic occupations above unit 6 makes Sima de las Palomas de Teba a most interesting new site in southern Iberia. It has the potential to study, in detail, the end of the Middle Paleolithic and the transition to the Upper Paleolithic, which will be tackled by future excavation of the site.

\section{Conclusions}

The sequence of the Sima de Las Palomas de Teba records various occupation events and represents an important new site for studying the presence of Neanderthals in southern Spain, especially during the latest phase. The comparatively rich and undisturbed archeological layers of units 9 and 10 and luminescence dating document that intense Neanderthal occupation took place in the studied part of the Sima de Las Palomas de Teba and ended with the first rockfall event. OSL and IRSL dating provided terminus ante quem of $39.4 \pm 2.6 \mathrm{ka}$ or $45.9 \pm 3.4 \mathrm{ka}$, respectively, for this occupation, whereas TL gave $48.7 \pm 8.4 \mathrm{ka}$ or even older. Further age control is needed to solve this chronological problem.

Units 4 to 7 accumulated between ca. $40 \mathrm{ka}$ and $23 \mathrm{ka}$. Unit 6, the uppermost Middle Paleolithic occupation, contains a significant number of artifacts in scattered distribution that apparently document ephemeral occupation by Late Neanderthals. However, artifacts and sediments of this unit could be reworked, hence the young luminescence age does not necessarily document the time of this second occupation phase. Undiagnostic lithic artifacts within units 4 and 5 were deposited after about $28 \mathrm{ka}$ and could represent occupation by anatomically modern humans.

A better understanding of the late Middle Paleolithic occupation history of the site affords excavation that goes beyond profile cleaning conducted so far. Unit 3 may provide an interesting insight in Chalcolithic occupation of Guadalteba district. The overall picture of the site fits well into the pattern of the Late Middle Paleolithic in southern Iberia. Neanderthal occupations tended to fade out within sequences and were often followed by a break in human occupation. Reoccupation of sites by Upper Paleolithic groups started only slowly and with some time lag.

\section{Acknowledgments}

We are grateful to the Consejería de Cultura de la Junta de Andalucía for authorizing our work in the framework of the project "Actividad Arqueológica Puntual en el Complejo Kárstico de Las Palomas de Teba (Málaga)". Thanks also to the institutions involved, especially, Consorcio Guadalteba, Grupo de Acción Local Guadalteba, Ayuntamiento de Ardales and Ayuntamiento de Teba. The German Research Foundation provided financial support for project C1 of the CRC806 "Our Way to Europe".

We gratefully acknowledge XRF analyses by Jens Protze and Marianne Dohms (Division of Physical Geography of RWTH Aachen University). Dr. Eileen Eckmeier, formerly at INRES-Soil Science of Bonn University, assisted in the determination and interpretation of color values. We thank María Blanca Ruiz and María José Gil for pollen studies. The help of students from the Escuela Taller during preparation of the profile and of all fellow researchers involved in the project is gratefully acknowledged. Special thanks go to Eduardo Vijande, Juan Jesus Cantillo, Antonio Barrena, Antonio Cabral, José María Gutiérrez, Maria del Mar Espejo, Serafin Becerra and Lidia Cabello for studies of lithic products. Constructive comments of C. Marean, J. Rios Garaizar and an anonymous reviewer significantly helped us to improve previous versions of the manuscript.

\section{Appendix A. Supplementary data}

Supplementary data to this article can be found online at http://dx. doi.org/10.1016/j.yqres.2016.01.007.

\section{References}

Adamiec, G., Aitken, M., 1998. Dose-rate conversion factors: update. Ancient TL 16, 37-50. Angelucci, D., 2010. The recognition and description of knapped lithic artifacts in thin section. Geoarchaeology 25, 220-232.

Angelucci, D.E., Zilhão, J., 2009. Stratigraphy and formation processes of the upper Pleistocene deposit at Gruta da Oliveira, Almonda karstic system, Torres Novas, Portugal. Geoarchaeology 24 (3), 277-310.

Atlas Climático Ibérico, 2011. Temperatura del aire y precipitación (1971-2000). Agencia Estatal de Meteorología de España and Departamento de Meteorologia e Clima, Instituto de Meteorologia de Portugal, p. 79.

Auclair, M., Lamothe, M., Hout, S., 2003. Measurement of anomalous fading for feldspar IRSL using SAR. Radiation Measurements 37, 487-492.

Barroso, C., De Lumley, H., 2006. La Grotte du Boquete de Zafarraya. Málaga, Consejería de Cultura, Junta de Andalucía, Sevilla.

Bar-Yosef, O., Van Peer, Ph., 2009. The chaîne opératoire approach in Middle Paleolithic Archaeology. Current Anthropology 50, 103-131

Bertran, P., Texier, J.P., 1999. Facies and microfacies of slope deposits. Catena 35, 99-121.

Boëda, E., 1994. Le concept Levallois: variabilité des méthodes. C.N.R.S., Paris (Monographie du CRA, 9).

Boëda, E., Geneste, J.M., Meignen, L., 1991. Identification des chaînes opératoires lithiques du Paléolithiques ancien et moyen. Paléo 2, 43-80.

Bordes, F., 1961. Typologie du Paléolithique ancien et moyen. Delmas, Bordeaux.

Bosinski, G., 1967. Die mittelpaläolithischen Funde im westlichen Mitteleuropa. Böhlau, Köln, Graz (Fundamenta A 4).

Bowman, S., Huntley, D., 1984. A new proposal for the expression of alpha efficiency in TL dating. Ancient TL 2, 6-8.

Brochier, J.E., 2002. Les sédiments anthropiques. Méthods d'études er perspectives. Géologie de la Préhistoire: méthodes, techniques, applications, Paris, Miskovsky J.-C. dir., GEOPRE éditions, pp. 453-477.

Bronk Ramsey, C., 2013. OxCal 4.2 Manual. https://c14.arch.ox.ac.uk/oxcalhelp/hlp_ contents.html.

Brown, N.D., Rhodes, E.J., Antinao, J.L., McDonald, E.V., 2015. Single-grain post-IR IRSL signals of K-feldspars from alluvial fan deposits in Baja California Sur, Mexico. Quaternary International 362, 132-138.

Buylaert, J.P., Murray, A.S., Thomsen, K.J., Jain, M., 2009. Testing the potential of an elevated temperature IRSL signal from K-feldspar. Radiation Measurements 44, 560-565.

Buylaert, J.P., Jain, M., Murray, A.S., Thomsen, K.J., Thiel, C., Sohbati, R., 2012. A robust feldspar luminescence dating method for Middle and Late Pleistocene sediments. Boreas 41, 435-451.

Buylaert, J.P., Murray, A.S., Gebhardt, A.C., Sohbati, R., Ohlendorf, C. Thiel, C., Wastegård, S., Zolitschka, B., The PASADO Science Team, 2013. Luminescence dating of the PASADO core 5022-1D from Laguna Potrok Aike (Argentina) using IRSL signals from feldspar. Quaternary Science Reviews 71, 70-80.

Canti, M.G., 1999. The production and preservation of faecal spherulites: animals, environment and taphonomy. Journal of Archaeological Science 26, 251-258.

Canti, M.G., 2003. Aspects of the chemical and microscopic characteristics of plant ashes found in archaeological soils. Catena 54, 339-361. 
Colarossi, D., Duller, G.A.T., Roberts, H.M., Tooth, S., Lyons, R., 2016. Comparison of paired quartz OSL and feldspar post-IR IRSL dose distributions in poorly bleached fluvial sediments from South Africa. Quaternary Geochronology 30, 233-238.

Cortés, M., 2011. Territorio y espacio. Paleolítico Medio y Superior en Andalucía. Un estado de la cuestión. Memorial Luis Siret. I Congreso de Prehistoria de Andalucía. Junta de Andalucía, Sevilla, pp. 163-172.

Cortéz-Sánchez, M., Morales-Muñiz, A., Simón-Vallejo, M.D., Bergadà-Zapata, M.M. Delgado-Huertas, A., López-Garcia, P., López-Sáez, J.A., Lozano-Francisco, M.C. Riquelme-Cantal, J.A., Roselló,-Izquierdo, E., Sánchez-Marco, A., Vera-Peláez, J.L., 2008. Palaeoenvironmental and cultural dynamics of the coast of Málaga (Andalusia, Spain) during the Upper Pleistocene and early Holocene. Quaternary Science Reviews 27, 2176-2193.

Courty, M.A., 2001. Microfacies analysis assisting archaeological stratigraphy. In: Goldberg, P., Holliday, V.T., Ferring, C.R. (Eds.), Earth Sciences and Archaeology. Kluwer Academic, New York, pp. 205-239.

Courty, M.A., Vallverdu, J., 2001. The microstratigraphic record of abrupt climate changes in cave sediments in the western Mediterranean. Geoarchaeology 16, 467-500.

Courty, M.A., Goldberg, P., Macphail, R.I., 1989. Soils and Micromorphology in Archaeology. Cambridge University Press, Cambridge, UK.

Delagnes, A., Meignen, L., 2006. Diversity of lithic production systems during the Middle Paleolithic in France: are there any chronological trends? In: Hovers, E., Kuhn, S.L. (Eds.), Transitions before the transitionEvolution and stability in the Middle Paleolithic and Middle Stone Age. Springer, New York, pp. 85-108

Domínguez-Bella, S., Ramos Muñoz, J., Weniger, G.-C., Cabello, L., 2014. Materias primas líticas. Estudios arqueomineralógicos y geoarqueológicos. In: Weniger, G.-C., Ramos, J. (Eds.), Sima de las Palomas de Teba (Málaga) Resultados de las investigaciones 1182 2011-2014. Ediciones Pinsapar, Málaga, pp. 145-153.

Duller, G.A.T., 2003. Distinguishing quartz and feldspar in single grain luminescence measurements. Radiation Measurements 37, 161-165.

Durand, N., Monger, H.C., Canti, M.G., 2010. Calcium carbonate features. In: Stoops, G., Marcelino, V., Mees, F. (Eds.), Interpretation of Micromorphological Features of Soils and Regoliths. Elsevier, Amsterdam, pp. 149-194.

Espigares, M.P., Ros-Montoya, S., Riquelme, J.A., Palmquvist, P., Martínez, B., 2014 Paleontología de las Sima de Las Palomas de Teba. In: Weniger, G.-C., Ramos, J. (Eds.), Sima de las Palomas de Teba (Málaga). Resultados de las investigaciones 2011-2014. Ediciones Pinsapar, Málaga, pp. 79-91.

Estévez, J., Villagran, X.S., Balbo, A.L., Hardy, K., 2014. Microtaphonomy in archaeological sites: the use of soil micromorphology to better understand bone taphonomy in archaeological contexts. Quaternary International 330, 3-9.

Fernández, S., Fuentes, N., Carrión, J.S., González-Sampériz, P., Montoya, E., Gil, G., VegaToscano, G., Riquelme, J.A., 2007. The Holocene and Upper Pleistocene pollen sequence of Carihuela Cave, southern Spain. Geobios 40 (1), 75-90.

Finlayson, C., Pachero, F.G., Rodriguez-Vidal, J., Fa, D.A., Gutierrez Lopez, J.M., Santiago Perez, A., Finlayson, G., Allue, E., Preysler, J.B., Caceres, I., Carrion, J.S., Fernández Jalvo, Y., Gled-Owen, C.P., Jimenez Espejo, F.J., Lopez, P., Lopez Saez, J.A., Riquelme Cantal, J.A., Sanchez Marco, A., Guzman, F.G., Brown, K., Fuentes, N., Valarino, C.A., Villalpando, A., Stringer, C.B., Ruiz, F.M., Sakamoto, T., 2006. Late survival of Neanderthals at the southernmost extreme of Europe. Nature 443, 850-853.

Galbraith, R.F., 2003. A simple homogeneity test for estimates of dose obtained using OSL. Ancient TL 21, 75-77.

Galbraith, R.F., Roberts, R.G., Laslett, G.M., Yoshida, H., Olley, J.M., 1999. Optical dating of single and multi-grains of Quartz from Jinmium rock shelter, northern Australia: part I, experimental design and statistical models. Archaeometry 41, 339-364.

Galván, B., Hernández, C.M., Mallol, C., Mercier, N., Sistiaga, A., Soler, V., 2014. New evidence of early Neanderthal disappearance in the Iberian Peninsula. Journal of Human Evolution 75, 16-27.

Giles Pacheco, F., Gutierrez López, J., Santiago Perez, A., Mata, E., 1998. Avance al estudio sobre poblamiento del Paleolítico superior en la cuenca media y alta del Río Guadelete (Cádiz). In: Sanchidrián, J., Simón Vallejo, M. (Eds.), Las Culturas del Pleistoceno Superior en Andalucía. Patronato de la Cueva de Nerja, Malaga, pp. 111-140.

Goldberg, P., Macphail, R.I., 2006. Practical and Theoretical Geoarchaeology. Blackwell (454 pp.).

Goldberg, P., Miller, C.E., Schiegl, S., Ligouis, B., Berna, F., Conard, N.J., Wadley, L., 2009. Bedding, hearths, and site maintenance in the Middle Stone Age of Sibudu Cave, KwaZulu-Natal, South Africa. Archaeological and Anthropological Sciences 1, 95-122.

Guérin, G., Discamps, E., Lahaye, C., Mercier, N., Guibert, P., Turq, A., Dibble, H.L., McPherron, S.P., Sandgathe, D., Goldberg, P., Jain, M., Thomsen, K., Patou-Mathis, M., Castel, J.-C., Soulier, M.-C., 2012. Multi-method (TL and OSL), multi-material (quartz and flint) dating of the Mousterian site of Roc de Marsal (Dordogne, France): correlating Neanderthal occupations with the climatic variability of MIS 5-3. Journal of Archaeological Science 39, 3071-3084.

Guérin, G., Frouin, M., Talamo, S., Aldeias, V., Bruxelles, L., Chiotti, L., Dibble, H.L., Goldberg, P. Hublin, J.-J., Jain, M., Lahaye, C., Madelaine, S., Maureille, B., McPherron, S.J.P. Mercier, N., Murray, A.S., Sandgathe, D., Steele, T.E., Thomsen, K.J., Turq, A., 2015. A multi-method luminescence dating of the Palaeolithic sequence of La Ferrassie based on new excavations adjacent to the La Ferrassie 1 and 2 skeletons. Journal of Archaeological Science 58, 147-166.

Higham, T., Douka, K., Wood, R., Ramsey, C.B., Brock, F., Basell, L., Camps, M., Arrizabalaga, A., Baena, J., Barroso-Ruiz, C., Bergman, C., Boitard, C., Boscato, P., Caparros, M., Conard, N.J., Draily, C., Froment, A., Galvan, B., Gambassini, P., Garcia-Moreno, A., Grimaldi, S., Haesaerts, P., Holt, B., Iriarte-Chiapusso, M., Jelinek, A., Jorda Pardo, J.F., Maíllo-Fernández, J., Marom, A., Maroto, J., Menendez, M., Metz, L., Morin, E., Moroni, A., Negrino, F., Panagopoulou, E., Peresani, M., Pirson, S., de la Rasilla, M., Riel-Salvatore, J., Ronchitelli, A., Santamaria, D., Semal, P., Slimak, L., Soler, J., Soler,
N., Villaluenga, A., Pinhasi, R., Jacobi, R., 2014. The timing and spatiotemporal patterning of Neanderthal disappearance. Nature 512, 306-309.

Hoffmann, D.L., Pike, A.W.G., Wainer, K., Zilhão, J., 2013. New U-series results for the speleogenesis and the Palaeolithic archaeology of the Almonda karstic system (Torres Novas, Portugal). Quaternary International 294, 168-182.

Hublin, J.-J., Barroso-Ruiz, C., Lara, P.M., Fontugne, M., Reyss, J., 1995. The Mousterian site of Zafarraya (Andalucia, Spain): dating and implications on the Palaeolithic peopling processes of Western Europe. Compte Rendus de l'Académie des Sciences, Paris, série Ila 321, pp. 931-937.

Huntley, D.J., Baril, M.R., 1997. The K content of the K-feldspars being measured in optical dating or in thermoluminescence dating. Ancient TL 15 (1), 11-13.

Huntley, D.J., Hancock, R.G.V., 2001. The Rb contents of K-feldspar grains being measured in optical dating. Ancient TL 19 (2), 43-46.

Huntley, D.J., Lamothe, M., 2001. Ubiquity of anomalous fading in K-feldspars and the measurement and correction for it in optical dating. Canadian Journal of Earth Sciences 38, 1093-1106.

Jennings, R., 2006. Neanderthal and Modern Human Occupation Patterns in Southern Iberia during the Late Pleistocene Period (PhD thesis) Hertford College, Oxford.

Jennings, R.P., Giles Pacheco, F., Barton, R.N.E., Collcutt, S.N., Gale, R., Gleed-Owen, C.P. Gutiérrez López, J.M., Higham, T.F.G., Parker, A., Price, C., Rhodes, E., Santiago Pérez, A., Schwenninger, J.L., Turner, E., 2009. New dates and palaeoenvironmental evidence for the Middle to Upper Palaeolithic occupation of Higueral de Valleja Cave, southern Spain. Quaternary Science Reviews 28, 830-839.

Jöris, O., Álvarez Fernández, A., Weninger, B., 2003. Radiocarbon evidence of the Middle to Upper Palaeolithic transition in Southwestern Europe. Trabajos de Prehistoria 60 (2), 15-38.

Karkanas, P., Goldberg, P., 2013. 6.23 Micromorphology of Cave Sediments. In: Shroder, J.F. (Ed.), Treatise on Geomorphology. Academic Press, San Diego, pp. 286-297.

Karkanas, P., Brown, K.S., Fisher, E.C., Jacobs, Z., Marean, C.W., 2015. Interpreting human behavior from depositional rates and combustion features through the study of sedimentary microfacies at site Pinnacle Point 5-6, South Africa. Journal of Human Evolution 85, 1-21.

Kehl, M., Burow, C., Cantalejo, P., Durán, J.J., Henselowsky, F., Klasen, N., Medianero, F.J. Ramos, J.J., Reicherter, K., Schmidt, C., Weniger, G.-C., 2013a. The Palaeolithic site Sima de Las Palomas de Teba, Southerrn Spain - site formation processes and chronostratigraphy. Proceedings of the VIII Reunión de Cuaternario Ibérico, La Rinconada, Sevilla, pp. 285-289.

Kehl, M., Burow, C., Hilgers, A., Navazo, M., Pastoors, A., Weniger, G.-C., Wood, R., Jordá Pardo, J.F., 2013b. Late Neanderthals at Jarama VI (Central Iberia)? Quaternary Research 80, 218-234.

Lenoble, A., Bertran, P., 2004. Fabric of Palaeolithic levels: methods and implications for site formation processes. Journal of Archaeological Science 31, 457-469.

Linstädter, J., Kehl, M., 2012. The Holocene archaeological sequence and site formation processes at Ifri Oudadane, NE Morocco. Journal of Archaeological Science 39 3306-3323.

López-Sáez, J.A., López-García, P., Cortés Sánchez, M., 2007. Paleovegetación de Cuaternario reciente: Estudio arqueopalinológico. In: Cortés Sánchez, M. (Ed.), Cueva Bajondillo (Torremolinos). Secuencia cronocultural y paleoambiental de Cuaternario reciente en la Bahía de Málaga.Centro de Ediciones de la Diputación de Málaga, Junta de Andalucía, Universidad de Málaga, Fundación Cueva de Nerja y Fundación Obra Social de Unicaja, Málaga, pp. 139-156

Mallol, C., Cabanes, D., Baena, J., 2010. Microstratigraphy and diagenesis at the upper Pleistocene site of Esquilleu Cave (Cantabria, Spain). Quaternary International 214 70-81.

Mallol, C., Hernández, C.M., Machado, J., 2012. The significance of stratigraphic discontinuities in Iberian Middle-to-Upper Palaeolithic transitional sites. Quaternary International 275, 4-13.

Maroto, J., Vaquero, M., Arrizabalaga, Á., Baena, J., Baquedano, E., Jordá, J., Julià, R., Montes, R., van der Plicht, J., Rasines, P., Wood, R., 2012. Current issues in late Middle Palaeolithic chronology: new assessments from Northern Iberia. Quaternary International 247, 15-25.

Marreiros, J., Bicho, N., 2013. Lithic technology variability and human ecodynamics during the Early Gravettian of Southern Iberian Peninsula. Quaternary International 318 90-101.

Medianero, F.J., Ramos, J., Palmqvist, P., Weniger, G., Riquelme, J.A., Espejo, M., Cantalejo, P., Aranda, A., Pérez-Claros, J.A., Figueirido, B., Espigares, P., Ros-Montoya, S., Torregrosa, V., Linstädter, J., Cabello, L., Becerra, S., Ledesma, P., Mevdev, I., Castro, A., Romero, M., Martínez-Navarro, B., 2011. The karst site of Las Palomas (Guadalteba County, Málaga, Spain): a preliminary study of its Middle-Late Pleistocene archaeopaleontological record. Quaternary International 243, 127-136.

Michel, V., Delanghe-Sabatier, D., Bard, E., Barroso Ruiz, C., 2013. U-series, ESR and 14C studies of the fossil remains from the Mousterian levels of Zafarraya Cave (Spain): a revised chronology of Neanderthal presence. Quaternary Geochronology 15, 20-33.

Miller, C.E., Conard, N.J., Goldberg, P., Berna, F., 2009. Dumping, sweeping and trampling: experimental micromorphological analysis of anthropogenically modified combustion features. Palethnologie 2, 25.37.

Mücher, H., van Steijn, H., Kwaad, F., 2010. Colluvial and Mass Wasting Deposits. In Stoops, G., Marcelino, V., Mess, F. (Eds.), Interpretation of Micromorphological Features of Soils and Regoliths. Elsevier, Amsterdam, pp. 37-48.

Murray, A.S., Wintle, A.G., 2000. Luminescence dating of quartz using an improved singlealiquot regenerative-dose protocol. Radiation Measurements 32, 57-73.

Murray, A.S., Wintle, A.G., 2003. The single aliquot regenerative-dose protocol: potential for improvements in reliability. Radiation Measurements 37, 377-381.

Murray, A.S., Thomsen, K.J., Masuda, N., Buylaert, J.P., Jain, M., 2012. Identifying wellbleached quartz using different bleaching rates of quartz and feldspar luminescence signals. Radiation Measurements 47, 688-695. 
Ortiz, J.E., Moreno, L., Torres, T., Vegas, J., Ruiz-Zapata, B., García-Cortés, Á., Galán, L., PérezGonzález, A., 2013. A 220 ka palaeoenvironmental reconstruction of the Fuentillejo maar lake record (Central Spain) using biomarker analysis. Organic Geochemistry 55, 85-97.

Pagliai, M., Stoops, G., 2010. Physical and Biological Surface Crusts and Seals. In: Stoops, G., Marcelino, V., Mess, F. (Eds.), Interpretation of Micromorphological Features of Soils and Regoliths. Elsevier, Amsterdam, pp. 419-440.

Peña, de la, P., Vega Toscano, G., 2013. The Early Upper Palaeolithic puzzle in Mediterranean Iberia. Quartär 60, 85-106.

Peresani, M. (Ed.), 2003. Discoid lithic technology. Advances and Implications. British Archaeological Reports, International Series, S1120.

Pettitt, P.B., Bailey, R.M., 2000. AMS radiocarbon and luminescence dating of Gorham's and Vanguard Caves, Gibraltar, and implications for the Middle to Upper Palaeolithic transition in Iberia. In: Stringer, C.B., Barton, R.N.E., Finlayson, J.C. (Eds.), Neanderthals on the Edge. Oxbow Books, Oxford, pp. 155-162.

Phillips, E., 2006. Micromorphology of a debris flow deposit: evidence of basal shearing, hydrofracturing, liquefaction and rotational deformation during emplacement. Quaternary Science Reviews 25, 720-738.

Prescott, J.R., Hutton, J.T., 1994. Cosmic ray contributions to dose rates for luminescence and ESR dating: large depths and long-term time variations. Radiation Measurements $23(2 / 3), 497-500$.

Preusser, F., 2003. IRSL dating of K-rich feldspars using the SAR protocol: comparison with independent age control. Ancient TL 21 (1), 17-23.

Preusser, F., Andersen, B.G., Denton, G.H., Schlüchter, C., 2005. Luminescence chronology of Late Pleistocene glacial deposits in North Westland, New Zealand. Quaternary Science Reviews 24, 2207-2227.

Ramos, J., 2013. Relationship and contacts of the Pleistocene hunter-gatherer societies with Mode III Technology between Northern Africa and the south Iberian Peninsula. In: Pastoors, A., Auffermann, B. (Eds.), Pleistocene Foragers on the Iberian Peninsula: Their Culture and Environment. Wissenschaftliche Schriften des Neanderthal Museums 7, Mettmann, pp. 35-53.

Ramos, J., Aguilera, R., Cortés, M., Bañares, M.M., 2005. El parque arqueológico de La Araña. Una vía para el estudio, la conservación y la puesta en valor de yacimientos paleolíticos. In: Santonja, M., Pérez-Gonzalez, A., Machado, M. (Eds.), Geoarqueoloía y patrimonio en la Península Ibérica y el entorno mediterráneo. ADEMA, Almazán, pp. 625-638.

Rethemeyer, J., Dewald, A., Fülöp, R., Hajdas, I., Höfle, S., Patt, U., Stapper, B., Wacker, L. 2013. Status report on sample preparation facilities for $14 \mathrm{C}$ analysis at the new Cologne AMS centre. Nuclear Instruments and Methods in Physics Research B 294 $168-172$.

Révillion, S., Tuffreau, A. (Eds.), 1994. Les industries laminaires au Paléolithique moyen. Actes de la table ronde internationale organisée par l'ERA 37 du CRA-CNRS à Villeneuve-d'Ascq 13 et 14 novembre 1991. C.N.R.S., Paris (Dossier de documentation archéologique, 18).

Richter, D., Tostevin, G., Škrdla, P., Davies, W., 2009. New radiometric ages for the Early Upper Palaeolithic type locality of Brno-Bohunice (Czech Republic): comparison of OSL, IRSL, TL and ${ }^{14} \mathrm{C}$ dating results. Journal of Archaeological Science 36, 708-720.
Richter, D., Angelucci, D.E., Dias, M.I., Prudêncio, M.I., Gouveia, M.A., Cardoso, G.J., Burbidge, C.I., Zilhão, J., 2014. Heated flint TL-dating for Gruta da Oliveira (Portugal): dosimetric challenges and comparison of chronometric data. Journal of Archaeological Science 41, 705-715.

Roberts, H.M., 2012. Testing Post-IR IRSL protocols for minimising fading in feldspars, using Alaskan loess with independent age control. Radiation Measurements 47, 716-724.

Ruiz Zapata, M.B., Gil, M.J., 2014. Estudio polínico de la secuencia. In: Weniger, G.-C., Ramos, J. (Eds.), Sima de las Palomas de Teba (Málaga). Resultados de las investigaciones 2011-2014. Ediciones Pinsapar, Málaga, pp. 67-77.

Schmidt, C., 2013. Luminescence Dating of Heated Silex - Potential to Improve Accuracy and Precision and Application to Paleolithic Sites (PhD thesis) University of Cologne (300 pp.).

Schmidt, C., Kreutzer, S., 2013. Optically stimulated luminescence of amorphous/microcrystalline $\mathrm{SiO}_{2}$ (silex): basic investigations and potential in archeological dosimetry. Quaternary Geochronology 15, 1-10.

Schmidt, I., Bradtmöller, M., Kehl, M., Pastoors, A., Tafelmaier, Y., Weninger, B., Weniger, G.-C., 2012. Rapid climate change and variability of settlement patterns in Iberia during the Late Pleistocene. Quaternary International 274, 179-204.

Stoops, G., 2003. Guidelines for the Analysis and Description of Soil and Regolith Thin Sections. Soil Science Society of America, Madison, WI.

Thiel, C. Buylaert, J.-P., Murray, A., Terhorst, B., Hofer, I. Tsukamoto, S., Frechen, M., 2011. Luminescence dating of the Stratzing loess profile (Austria) - testing the potential of an elevated temperature post-IR IRSL protocol. Quaternary International 234, 23-31.

Vallespí, E., 1986. El Paleolítico inferior y medio en Andalucía. Homenaje a Luis Siret (1934-1984). Junta de Andalucía, Sevilla, pp. 59-66.

Vega Toscano, L.G., 1988. El Paleolítico Medio del Sureste Español y Andalucía Oriental. Universidad Complutense, Madrid.

Vegas, J. Ruiz-Zapata, B., Ortiz, JE. Galán, L., Torres, T. García-Cortés, Á Gil-García, M.J. Pérez-González, A., Gallardo-Millán, J.L., 2010. Identification of arid phases during the last 50 cal ka BP from the Fuentillejo maar-lacustrine record (Campo de Calatrava Volcanic Field, Spain). Journal of Quaternary Science 25, 1051-1062.

Wallinga, J., Murray, A.S., Wintle, A.G., 2000. The single-aliquot regenerative-dose (SAR) protocol applied to coarse-grain feldspar. Radiation Measurements 32, 529-533.

Weniger, C.-H., Ramos Muñoz, J. (Eds.), 2014. Sima de las Palomas de Teba (Málaga). Resultados de las investigaciones 2011-2014. Ediciones Pinsapar, Málaga.

Wood, R.E., Barroso, C., Caparros, M., Jorda, J.F., Galvan Santos, B., Higham, T.F.G., 2013. Radiocarbon dating casts doubt on the late chronology of the Middle to Upper Palaeolithic transition in southern Iberia. Proceedings of the National Academy of Sciences 110, 2781-2786.

Zilhão, J., 2006. Chronostratigraphy of the Middle to- Upper Paleolithic transition in the Iberian Peninsula. Pyrenae 37, 7-84.

Zilhão, J., Davis, S.J.M., Duarte, C., Soares, A.M.M., Steier, P., Wild, E., 2010. Pego do Diabo (Loures, Portugal): dating the emergence of anatomical modernity in Westernmost Eurasia. PloS One 5 (1), e8880. 